Final Report

FHWA/IN/JTRP-2007/15

\title{
A Prescriptive Analysis of the Indiana Coal Transportation Infrastructure
}

\author{
A Cost-Sharing Project with the \\ Center for Coal Technology Research \\ Purdue University \\ West Lafayette, Indiana \\ by \\ Thomas F. Brady, Ph.D. \\ Associate Professor \\ Industrial Engineering Technology \\ Purdue University \\ North Central Campus \\ and \\ Chad M. Pfitzer \\ Purdue Extension-Daviess County \\ Agriculture \& Natural Resources \\ Economic \& Community Development \\ Joint Transportation Research Program \\ Project No. C-36-54III \\ File No. 3-3-61 \\ SPR-3015 \\ Prepared in Cooperation with the \\ Indiana Department of Transportation and the \\ U.S. Department of Transportation \\ Federal Highway Administration
}

The contents of this report reflect the views of the authors, who are responsible for the facts and the accuracy of the data presented herein. The contents do not necessarily reflect the official views or policies of the Indiana Department of Transportation or the Federal Highway Administration at the time of publication. This report does not constitute a standard, specification, or regulation.

Purdue University

May 2007 


\begin{tabular}{|c|c|c|}
\hline $\begin{array}{l}\text { 1. Report No. } \\
\text { FHWA/IN/JTRP-2007/15 }\end{array}$ & 2. Government Accession No. & 3. Recipient's Catalog No. \\
\hline \multirow{2}{*}{\multicolumn{2}{|c|}{$\begin{array}{l}\text { 4. Title and Subtitle } \\
\text { A Prescriptive Analysis of the Indiana Coal Transportation Infrastructure }\end{array}$}} & $\begin{array}{l}\text { 5. Report Date } \\
\text { May } 2007\end{array}$ \\
\hline & & 6. Performing Organization Code \\
\hline \multicolumn{2}{|l|}{$\begin{array}{l}\text { 7. Author(s) } \\
\text { Thomas M. Brady and Chad M. Pfitzer }\end{array}$} & $\begin{array}{l}\text { 8. Performing Organization Report No } \\
\text { FHWA/IN/JTRP-2007/15 }\end{array}$ \\
\hline \multirow{2}{*}{\multicolumn{2}{|c|}{$\begin{array}{l}\text { 9. Performing Organization Name and Address } \\
\text { Joint Transportation Research Program } \\
550 \text { Stadium Mall Drive } \\
\text { Purdue University } \\
\text { West Lafayette, Indiana 47907-2051 }\end{array}$}} & 10. Work Unit No. \\
\hline & & $\begin{array}{l}\text { 11. Contract or Grant No. } \\
\text { SPR-3015 }\end{array}$ \\
\hline \multirow{2}{*}{\multicolumn{2}{|c|}{$\begin{array}{l}\text { 12. Sponsoring Agency Name and Address } \\
\text { Indiana Department of Transportation } \\
\text { State Office Building } \\
100 \text { North Senate Avenue } \\
\text { Indianapolis, IN } 46204\end{array}$}} & $\begin{array}{l}\text { 13. Type of Report and Period Covered } \\
\text { Final Report }\end{array}$ \\
\hline & & 14. Sponsoring Agency Code \\
\hline
\end{tabular}

15. Supplementary Notes

Prepared in cooperation with the Indiana Department of Transportation and Federal Highway Administration.

\section{Abstract}

This report presents the findings of a scoping study of Indiana's coal transportation infrastructure. Throughout the literature search and investigative phases of this project, it was clear that there exists growing awareness of the importance that transportation plays in the domestic coal industry. There is evidence that suggests transportation costs may be higher than the cost of mining coal. Numerous studies suggest that coal transportation can be developed and utilized for significant competitive economic advantage. The Powder River Basin area in Wyoming is a stellar example of how the combination of a large natural resource and careful transportation planning can result in tremendous economic advantage to an area. It is estimated that nearly 40 percent of the coal burned in U.S. power plants comes from this area, which has increased coal production nearly 40 percent since 1997 . Significant rail infrastructure investments have been made between this region and the national rail infrastructure making it cost advantageous to ship Wyoming coal nationwide.

The objective of this project was to quantitatively examine the coal transportation infrastructure relative to power plant operations in the state of Indiana and construct a computer simulation model that can be used to quantitatively assess rail scenarios. Computer simulation is a tool that can provide proof of concept. Using simulation, railroads can be proposed, constructed, and operated on a computer. Experiments can be conducted to optimize the operations of the scenario.

The intent of this project was not to develop a truly comprehensive analysis of the Indiana position and potential with respect to the national coal transportation, but rather conduct a scoping study that would highlight the issue and suggest a methodology for further analysis. Throughout the duration of this project, we were encouraged by the proliferation of articles about coal and coal transportation, the citing of the importance of logistics and transportation infrastructure to Indiana's future economic success by the Indiana Chamber of Commerce, and the numerous requests for scenario studies from interested parties such as the Ports of Indiana, Vectren Energy, the City of Vincennes, Duke Energy, and NiSource. Future development of the methodology contained in this report into a comprehensive tool that can provide policy direction the state of Indiana is recommended.

\begin{tabular}{|l|l|l|l|l|}
\hline 17. Key Words & \multicolumn{1}{l|}{$\begin{array}{l}\text { 18. Distribution Statement } \\
\text { No restrictions. This document is available to the public through the } \\
\text { National Technical Information Service, Springfield, VA 22161 }\end{array}$} \\
\hline \begin{tabular}{c|c|c|} 
19. Security Classif. (of this report) \\
Unclassified
\end{tabular} & $\begin{array}{l}\text { 20. Security Classif. (of this page) } \\
\text { Unclassified }\end{array}$ & 21. No. of Pages Price \\
\hline
\end{tabular}




\section{Table of Contents}

$\underline{\text { Item }}$

List of Figures

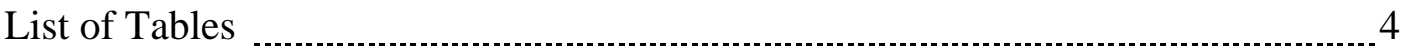

Acknowledgments

Preface

Chapter $1 \quad$ Introduction

Chapter 2 Methodology

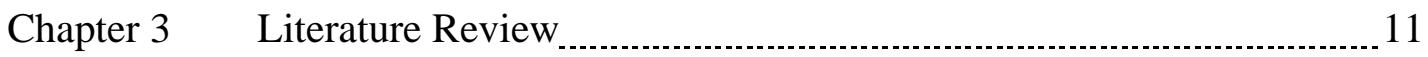

Chapter 4 Demand and Supply States of Indiana Coal

Chapter 5 Rail Transportation of Indiana Coal $\quad$ _................................................. 17

Chapter 6 Operational Aspects of Coal Transportation_.............................. 23

Chapter 7 Coal Transportation Simulation Model _................................... 25

Chapter 8 Scenario 1: Francisco Mine to Wabash River Power Plant _............ 28

Chapter 9 Scenario 2: Vincennes Railroad Relocation _................................ 31

Chapter 10 Scenario 3: Farmersburg Mine to Schahfer Power Plant ................... 33

Chapter 11 The Indiana Coal Corridor

Chapter 12 Scenario 4: The Indiana Coal Corridor with Light Passenger Rail .... 39

Chapter 13 Optimal Allocation of Infrastructure Investment _............................ 43

Chapter 14 Conclusions and Suggestions for Further Research _......................... 47

References

Appendix 1: Mine to Power Plant Timetables (Separate Volume)

Appendix 2: Indiana Coal Corridor Timetables (Separate Volume)

APPENDICES 1 and 2 are available on the CCTR website:

http://discoverypark.purdue.edu/wps/portal/Energy/CCTR_Research 


\section{List of Figures}

\section{Figure Title}

1 Sample Railroad Route Timetable 9

2 Indiana Power Plant Generation Growth

3 Indiana Rail Infrastructure

4 Average Rail Class Summary .....

5 Average Rail Class by Power Plant

6 Average Rail Class by Mine 20

7 Average Rail Speed Summary 20

$8 \quad$ Average Rail Speed by Mine …………………………………........... 21

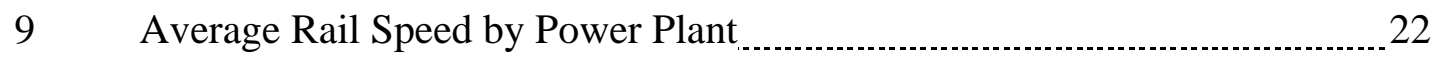

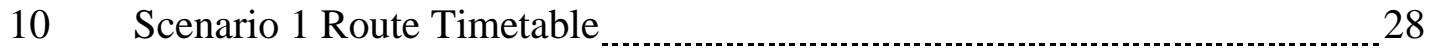

11 Scenario 1 Animation Screen ……………………........................... 29

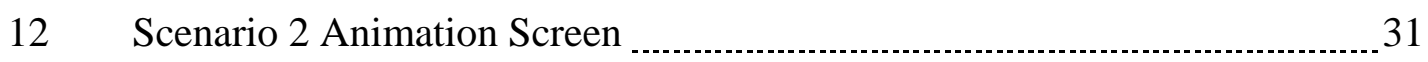

13 Scenario 3 Route Timetable _................................................................ 34

14 Scenario 3 Animation Screen ………………………………................. 35

15 Coal Inventory Level Based On One Unit Train _............................................ 35

16 Coal Inventory Level Based On Two Unit Trains _........................................ 36

17 Coal Inventory level Based On Class 1 Rail Infrastructure _.......................36

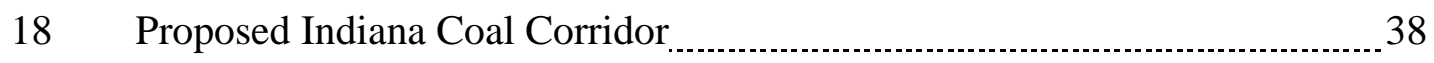

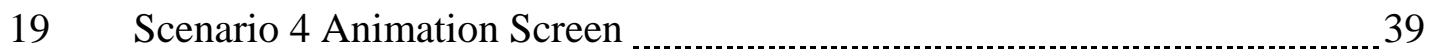

20 Scenario 4 Route Timetable

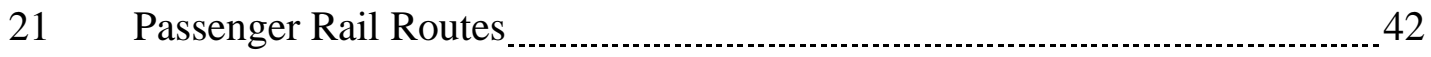




\section{List of Tables}

Table Title

1 Coal Consumption at Indiana’s Ten Largest Power Plants

2 Coal Production at Indiana's Ten Largest Coal Mines

3 Rail Class Definition

4 Generic Simulation Model Parameters

5 Simulation Model Delay Parameter Values...

6 Simulation Model Delay Probability Values

$7 \quad$ Simulation Model Power Plant Coal Demand Parameter Values

8 Scenario 1 Factorial Design.

9 Scenario 2 Vehicle Arrival Distribution

10 Hypothetical Rail Upgrade Costs

11 Optimization Formulation Data

12 Distribution of Miles by Class

13 Optimization Summary

\section{Page} 15 16 18 26 27 27 27 30 32 43 46 44 45 


\section{ACKNOWLEDGMENTS}

The authors would like to thank the following groups and individuals for their contributions to this project:

The Center for Coal Technology Research (CCTR) in the Energy Center at Discovery Park at Purdue University under the direction of Marty Irwin, including Dr. Brian Bowen, Dr. F. T. Sparrow, and Board of Directors member Mark Newlin of Duke Energy.

The Joint Transportation Research Program (JTRP), a research partnership between the School of Civil Engineering at Purdue University and the Indiana Department of Transportation(INDOT) under the direction of Dr. Kumares Sinha, including Ms. Karen Hatke and Study Advisory Committee members including Keith Bucklew, John Jordan, Mike Riley, Dave Franklin, Tom Beck, Steve Smith, Larry Heil, and Samy Noureldin.

The contents of this report reflect the views of the authors, who assume responsibility for the facts and data presented within. The content of this report does not necessarily reflect the views and policies of the Indiana Department of Transportation or the Center for Coal Technology Research.

Correspondence can be made with the primary author at the following address:

Thomas F. Brady, Ph.D.

Purdue University North Central

1401 South US 421

Westville, IN 46391

219-785-5456

tbradyjr@pnc.edu 


\section{PREFACE}

This report presents the findings of a scoping study of Indiana's coal transportation infrastructure. Throughout the literature search and investigative phases of this project, it is clear that there exists growing awareness of the importance that transportation plays in the domestic coal industry. There is evidence that suggests transportation costs may be higher than the cost of mining coal. Numerous studies suggest that coal transportation infrastructures can be developed and utilized for significant competitive economic advantage. The Powder River Basin area in Wyoming is a stellar example of how the combination of a large natural resource and careful transportation planning can result in tremendous economic advantage to an area. It is estimated that nearly forty percent of the coal burned in US power plants comes from this area, which has increased coal production nearly forty percent since 1997. Significant rail infrastructure investments have been made between this region and the national rail infrastructure, making it cost advantageous to ship Wyoming coal nationwide.

The Indianapolis Star ran a story that included the following statement about the state of Indiana: "People call us the Saudi Arabia of coal. But if you don't get it to the power plants, it doesn't matter." [13] This statement is the essence of the research questions addressed in this project: Indiana has the coal, is centrally located in national rail infrastructure, but do they have the connective rail infrastructure to take advantage of this position? The significance of the problem was succinctly described in a project support letter from Northern Indiana Public Service Company (NIPSCO), a large Indiana-based coal burning utility that stated "Over the years, NIPSCO has routinely reviewed the potential of burning Indiana coal; however, it has not been economical to do so, primarily from a transportation perspective.”

The objective of this project is to quantitatively examine the coal transportation infrastructure relative to power plant operations in the state of Indiana and construct a computer simulation model that can be used to quantitatively assess rail scenarios. Computer simulation is a tool that can provide proof of concept. Using simulation, railroads can be proposed, constructed, and operated on a computer. Experiments can be conducted to optimize the operations of the scenario.

The intent of this project was not to develop a truly comprehensive analysis of the Indiana position and potential with respect to the national coal transportation, but rather conduct a scoping study that would highlight the issue and suggest a methodology for further analysis Throughout the duration of this project, we have been encouraged by the proliferation of articles about coal and coal transportation, the citing of the importance of logistics and transportation infrastructure to Indiana's future economic success by the Indiana Chamber of Commerce, and the numerous requests for scenario studies from interested parties such as the Ports of Indiana, Vectren Energy, the city of Vincennes, Duke Energy, and NiSource. We feel that this project is in the right place at the right time. Additionally, we stand ready to put together a follow-on proposal that will more fully develop the methodology contained in this report into a comprehensive tool that can provide policy direction to the state of Indiana to succeed in this emerging area. 


\section{Chapter 1}

\section{INTRODUCTION}

The United States is at the crossroads of a looming energy dilemma. Global economic development has intensified the demand for basic energy commodities such as oil and gas. This demand has provided the impetus for a reevaluation of alternative energy sources. The state of Indiana is strategically positioned in this environment due to its central location and abundant source of coal. To exploit this position from an economic standpoint requires that appropriate transportation infrastructure be in place.

The state of Indiana possesses a vast rail infrastructure. Indiana ranks ninth in the United States in terms of track mileage with over four thousand miles. Indiana has five Class 1 railroads operating in the state along with thirty-five regional, short track, and line haul carriers.

As with any commodity, market price is a combination of factors that can be separated into two major categories. The first category consists of the process that extracts or creates the commodity. The second category consists of the process that moves the commodity to the customer. Historically, these two activities have been decoupled. With the advent of economic globalization in the 1990's the supply chain concept, a total systems approach became the norm when analyzing economic activity. A simple definition of the supply chain concept is:

Supply chain management is a set of approaches utilized to efficiently integrate suppliers, manufacturers, warehouses, and stores, so that merchandise is produced and distributed at the right quantities, to the right locations, and at the right time, in order to minimize system-wide costs while satisfying service level requirements [24].

The basis of this project is to use the supply chain concept to analyze and suggest improvements to the Indiana coal transportation network. While the actual price of coal mining/extraction may be constant across major producers, the cost of transporting it to the customer may be highly variable, thus suggesting a major competitive dimension that may be exploited. The objective of this project is to examine the transportation component of coal movement using the Indiana transportation infrastructure and develop knowledge as to how the current inflow and outflow environment works. Once the coal transportation infrastructure is defined, we will seek to optimize it to competitive levels through suggested capital improvements.

The movement of goods through a transportation infrastructure is subject to numerous external factors characterized by two attributes: process variation and dependency. Process variation is present in any activity and presents numerous challenges to efficiency. In particular, the current United States rail infrastructure includes many 
bottlenecks that make 'average' transport times highly variable. Dependency refers to the concept that any supply chain is composed of a number of links and the interdependencies of the links determine overall efficiency of the supply chain.

The primary outcome of this project will be the characterization of the capacity of the Indiana transportation infrastructure along time and cost dimensions as a link in the coal-fired power plant network. Once accurate projections of the capacity are known, improvements will be developed and analyzed that optimize the efficiency of Indiana's coal transportation infrastructure on a scenario by scenario basis. The primary output of this project will be a simulated environment that can be used to accurately project and build Indiana's coal transportation infrastructure into one that can add competitive value to Indiana's coal industry, allowing the state to compete nationally.

The United States possesses a vast railroad infrastructure. Approximately one hundred forty thousand miles of rail exist across the country shared by over five hundred railroad companies. The railroad infrastructure is a driving force in the globalization of the US economy. As cross country container traffic has increased, traditional rail transport commodities such as coal have been forced to compete for scarce locomotive and track right resources. This competition has increased the cost of coal transportation. The state of Indiana ranks ninth nationally in the number of miles of railroad tracks. Indiana also possesses vast coal reserves.

This project report presents the details of a simulation-based study of Indiana's coal transportation infrastructure. Numerous literature sources point to a growing awareness of the importance that transportation plays in the domestic coal industry. Evidence even suggests that transportation costs are significantly higher than the cost of the coal itself. Numerous studies suggest that coal transportation infrastructures can be developed and utilized to significant competitive economic advantage. The Powder River Basin area in Wyoming is a stellar example of how the combination of a large natural resource with strategic transportation planning can result in tremendous economic advantage. It is estimated that nearly forty percent of the coal burned in US power plants comes from this area, which has increased coal production nearly forty percent since 1997. Significant rail infrastructure investments have been made to connect this region to the national rail infrastructure, making it cost advantageous to ship Wyoming coal nationwide.

The basis of the study presented in this paper is to use simulation and the supply chain concept to analyze and suggest improvements to the Indiana coal transportation network. While the actual price of coal mining/extraction may be constant across major producers, the cost of transporting it to the customer may be highly variable, thus suggesting a major competitive dimension that may be exploited. Through the use of simulation modeling analysis, the capacity of the Indiana coal transportation infrastructure will be determined. Once accurate projections of the capacity are known, improvement scenarios will be developed and analyzed to optimize the efficiency of Indiana's coal transportation infrastructure, adding competitive value to the state of Indiana's vast coal industry. 


\section{Chapter 2}

\section{METHODOLOGY}

This chapter describes the methodology used to carry out the analysis presented by this report. The intent of this project was to examine the coal transportation infrastructure in the state of Indiana. As detailed in Chapter 1, Indiana has a vast rail infrastructure. To provide a cursory, yet thorough analysis in the time frame of the project, it was necessary to limit the scope. The scope of this project was limited to considering only the ten largest coalmines and the ten largest coal-fired power plants within the state of Indiana.

The movement of trains through local, state, and national rail infrastructure is a complex process. Trains move from point to point through a combination of owned or leased rail lines, and negotiated rights. The movement of trains through the network is controlled by the use of timetables. A sample timetable is shown in Figure 1. One of the major contributions of this project is the construction of a comprehensive set of timetables that define connections between the set of power plants and mines. The complete set of timetables for all combinations of the ten power plants and ten coalmines is presented in Appendix 1. The complete set of timetables corresponding to the Indiana Coal Corridor, a concept defined in Chapter 11 is presented in Appendix 2.

INDIANA COAL RAILROAD TIMETABLE: ROUTE 2

\begin{tabular}{|c|c|c|c|c|c|c|c|}
\hline \multirow[t]{2}{*}{ STATION NAME } & \multirow{2}{*}{$\begin{array}{l}\text { MILE } \\
\text { POST }\end{array}$} & \multicolumn{4}{|c|}{ TRACK } & \multirow[t]{2}{*}{ NOTATION } & \multirow[t]{2}{*}{ INTERLOCKS } \\
\hline & & OWNER & NUMBER & CLASS & SPEED & & \\
\hline \multicolumn{8}{|c|}{ READ DOWNWARD FOR SOUTHBOUND } \\
\hline CPHOLT & 172.5 & IN, INCR & 1 & 1 & 10 & $\mathrm{~T}$ & $\begin{array}{c}1, C / N D, \\
C S X T\end{array}$ \\
\hline MOORESVILLE & 185.0 & INCR & 1 & 2 & 25 & & \\
\hline MARTINSVILLE & 199.0 & INCR & 1 & 2 & 25 & & \\
\hline WHITAKER & 209.0 & INCR & 1 & 2 & 25 & $P$ & \\
\hline SPENCER & 221.5 & INCR & 1 & 2 & 25 & & \\
\hline WORTHINGTON & 240.5 & INCR & 1 & 2 & 25 & $\mathrm{P}, \mathrm{Y}$ & \\
\hline SWITZ CITY & 247.5 & INCR & 1 & 2 & 25 & A & 3 \\
\hline BEEHUNTER & 254.5 & INCR & 1 & 1 & 40 & A & 4,6 \\
\hline ELNORA & 260.5 & INCR & 1 & 1 & 40 & $\mathrm{~A}$ & 5 \\
\hline CHAPPEL & 279.5 & INCR & 1 & 2 & 25 & $M$ & CSXT \\
\hline PETERSBURG & 296.5 & INCR & 1 & 2 & 25 & & \\
\hline ASHBY YARD & 298.0 & INCR & 1 & 2 & 25 & $\mathrm{~B}, \mathrm{E}, \mathrm{Y}$ & \\
\hline OAKLAND CITY & 308.5 & INCR & 1 & 2 & 25 & $\mathrm{~A}$ & NS \\
\hline GRAY JCT & 309.5 & INCR & 1 & 2 & 25 & & \\
\hline BUCKSKIN & 317.5 & INCR & 1 & 2 & 25 & $\mathrm{~T}$ & 7 \\
\hline STRAIGHT LINE JCT & 337.5 & $\begin{array}{l}\text { CSXT, } \\
\text { INCR }\end{array}$ & 1 & 2 & 25 & & \\
\hline \multicolumn{8}{|c|}{ BETWEEN STRAIGHT LINE JCT AND WANSFORD YARD CSXT TIMETABLE GOVERNS. } \\
\hline WANSFORD YARD & 338.0 & CSXT & 1 & 1 & 10 & $\bar{Y}$ & CSXT \\
\hline \multicolumn{8}{|c|}{ READUPWARD FOR NORTHBOUND } \\
\hline
\end{tabular}

Figure 1

Sample Railroad Route Timetable

A computer simulation model was then developed that used the timetables as a representation of the Indiana rail infrastructure. Railroads are complex systems 
composed of two components: an infrastructure and a set of operating rules. Using this model, detailed operational scenarios representing both current and proposed rail infrastructure improvements were constructed to allow what-if analysis to be performed.

The simulation models developed in this project are simple models designed to demonstrate the power of the technology. As in any simulation study, the users are the ones who determine the quality and usefulness of the results obtained. The models presented in this report represent stage one in the simulation model development lifecycle. The issues and scenarios presented are simply the ideas of the authors and suggestions from the project advisory boards. In some cases, hypothetical data for scenario development was used. These models can easily be embellished to examine specific scenarios proposed by interested parties. 


\section{Chapter 3}

\section{LITERATURE REVIEW}

This chapter presents a brief survey of literature relative to issues addressed in this project. The focus of the literature search was to find supporting documentation for the relevant questions posed by this project concerning the coal-based rail infrastructure. As the literature search progressed, seven themes became apparent. The remainder of this chapter is organized by theme.

\subsection{Coal Use is Increasing}

The use of coal in the United States has seen a significant increase as the demand for electricity rises. It is estimated that the average American consumes twenty pounds per day. Coal has emerged as the default fuel of choice since it can be shipped via boats, trucks and trains it is easy to store and burn, and can be stored for months [10].

Coal-fired power production has increased $26 \%$ since 1995 [15]. There are approximately 120 new coal-fired power plants valued at 99 billion dollars in the planning or construction phases. During heat waves in summer months, coal-fired power plants work overtime to supply consumer demand. Schahfer generating station in Wheatfield, Indiana set a new power use record on July 26, 2006 as the station's coal handling department bunkered more than 21,000 tons of coal [27]. Figure 2 shows the percentage increase in production at the largest coal-fired power plants in Indiana over the last five years.

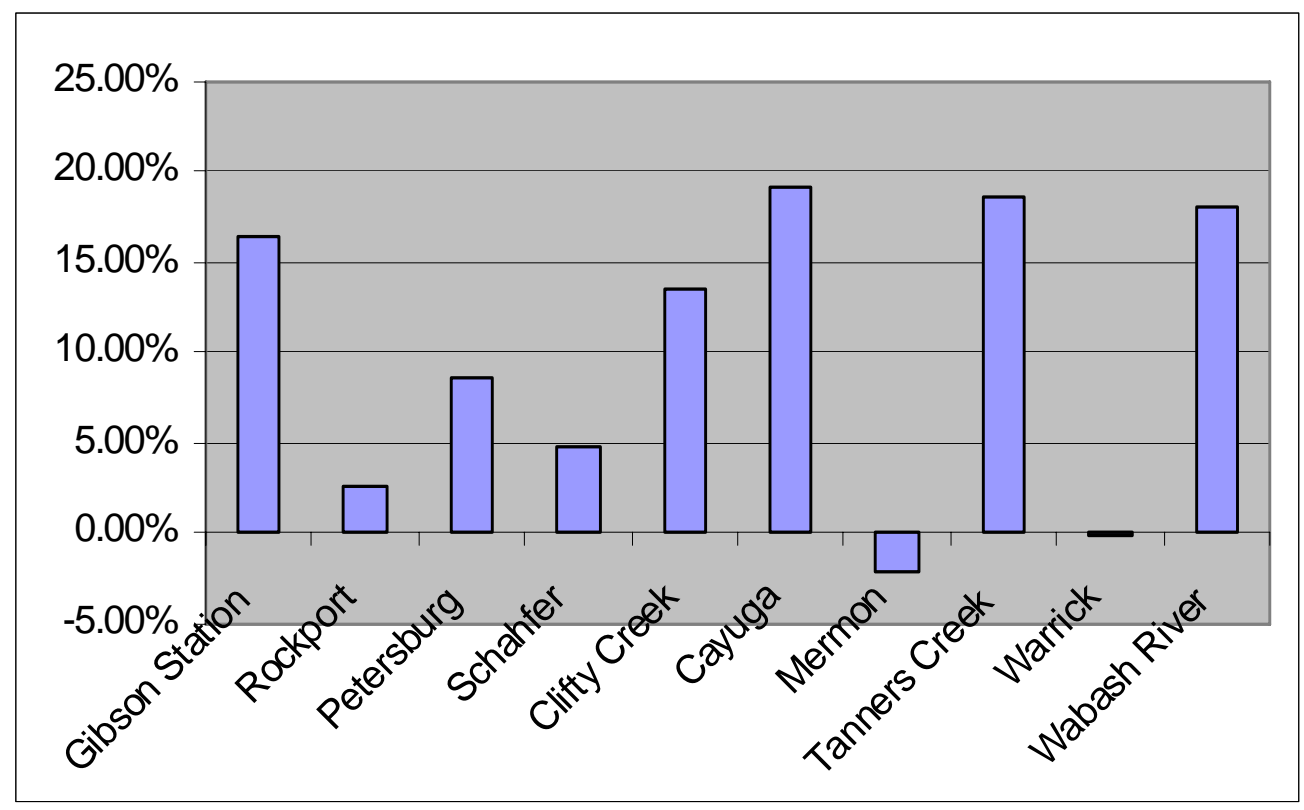

Figure 2

Indiana Power Plant Generation Growth 
As the demand for coal increases, significant challenges exist in the coal supply chain. It is not at all clear, moreover, how well today's infrastructure could support the rapid adoption of hybrid vehicles that draw on electricity [7]. This wealth of coal can't flow freely through the US economy until costly and difficult fixes are applied across the whole business of mining, transporting, and burning coal [15]. Railroad congestion is seen as the biggest bottleneck to expansion of coal-fired power plants [10].

\subsection{Transportation is a Significant Component of Coal Economics}

Coal is a unique commodity in that the transportation cost is more than the extraction cost. Thus, when coal is purchased, a majority of the contract price goes towards moving it to the required destination. Depending on the proximity of the customer to the mine and the transportation resources available for delivering coal to that customer, transportation charges can range from 4 to $41 \%$ of the delivered cost. As a consequence, the availability and cost of transportation constitute one of the most important factors in the marketability of coal [3]. Estimates indicate that coal from the Powder River basin in Wyoming can be purchased for as little as \$6 per ton with a transportation cost of \$30 per ton [10].

To capitalize on this situation, investment has been made in the shipping aspect of coal. Shipping costs of coal on transcontinental railroads such as the BNSF have helped Western-mined coal make significant inroads into traditional Illinois coal markets [22]. Efforts have been made to secure federal funding to create additional rail infrastructure including plans to "morph the DM\&E, a decrepit \$220 million a year line into a 2800 mile, 1 billion plus per year coal carrying artery” [15].

\subsection{The National Rail Infrastructure is Capacity Constrained}

Shipping coal by rail is the preferred method. Approximately eighty-five percent of coal moved nationally is by rail, while Indiana moves nearly seventy percent by rail [4]. Coal producers and electric utilities rely on a vibrant rail system. At present, the rail network is inadequate with bottlenecks found across the nation and particularly in Wyoming [7]. If Indiana intends to become active in the national coal market, the capacity constrained national rail infrastructure could hinder the effort. An estimated 1/3 of US rail cargo flows through Chicago. The current rail market boom underscores the need for better infrastructure, particularly in the Midwest [9].

Railroad congestion is the biggest bottleneck to expansion of coal-fired plants Rail delays are increasing as are train derailments, breakdowns, human error, and weather [10]. The federal government is keenly aware of the congestion problem and its consequences for the economy. The 2006 Transportation Bill increased the FRA loan budget from 3.5 to 35 billion and required the FRA give priority to projects that "alleviate rail capacity problems [26]. 


\subsection{Coal is Facing Challenges From Other Commodities for Use of Rail Resources}

For decades, coal occupied the top position in terms of tonnage moved over the rails. Lately it has been displaced by consumer goods pouring into West Coast ports from Asia [21]. The most telling statistic that foreshadows this issue is that coal represents fortytwo percent of the rail tonnage, but only twenty percent of the revenue [20]. Intermodal trail traffic represents only six percent of the tonnage, but fifteen percent of the revenue. As the United States economy continues to transition from goods to services, one can only expect intermodal traffic to continue to increase.

The rail industry is also watching the ethanol story unfold. Ethanol can't move by pipeline, so if it does hit the big time, railroads may stand to gain a major source of traffic and revenue [28].

\subsection{Railroads Control Coal Transportation Pricing}

As the number of class 1 railroads has decreased, these railroads have rationalized the amount of track and equipment available. This has given them leverage in moving commodities over long distances. In certain markets, railroads have been accused of monopoly pricing [10]. Coal delivery by rail has become increasingly unreliable and expensive.

The effects of monopoly pricing on a commodity such as coal can have a devastating impact on the economy for numerous reasons. Railroads can determine the price and availability of coal and use this leverage over customers. As monopoly pricing decreases competition, decreased investment in the rail infrastructure will exacerbate congestion problems, causing financial implications for coalmines and power plants. Evidence of monopoly behavior can be seen in a case that showed 'even a brand-new rail line would be able to serve Otter Tail's coal needs at a lower cost than BNSF [10].

\subsection{Rail Transportation is Plagued by Variability}

Consolidation has left the rail industry with just a half dozen major operators. This can cause paralyzing railroad bottlenecks when something goes wrong. Strong demand for coal is putting strains on the national coal supply chain. Utilities have reported getting coal deliveries in the nick of time.

Coal delivery by rail has become increasingly unreliable and expensive [6]. .”.Arkansas Electric has a problem that is a growing concern for many US utilities: It can't get enough coal to run its power plants because the trains that serve as its supply line aren't running on time.” [21]

The net effect of supply chain variability is an increase in the inventory that must be kept on hand. Most coal-fired power plants keep a thirty to forty day supply on hand [10]. This increases the rates consumers pay for electricity and restrains utility profits. 
3.7 PRB is Being Developed as a National, Long Term, Volume Commodity

For the past twenty years, the Powder River Basin (PRB) in Wyoming has developed into an economic powerhouse of coal. Statistics support the argument. Forty percent of the coal burned in the United States comes from Wyoming. Between 1997 and 2004, coal production in Wyoming grew forty percent. Wyoming coal productivity is thirty-nine tons per employee hour [10]. Train counts in PRB coalfields averaged 65.4 per day in May 2006. The Union Pacific unloaded a record 5304 coal trains in the first 5 months of 2006 [6]

The coal transportation infrastructure has enabled this growth. The Union Pacific and BNSF spent $\$ 100$ million in capacity expansion in PRB alone in 2006. They built 40 miles of third and fourth line track [28]. Heavy duty rail infrastructure will allow heavier trains to operate. A Union Pacific study noted that '...operating 286,000 pound cars instead of 263,000 pound cars will require approximately 1500 fewer trains, 15,000 fewer crew starts, 770 fewer locomotives and 29,500 fewer cars. In addition, UP has lengthened unit coal trains from 105 to 135 cars [11]. Newer power plants can handle 150 car trains.

This plan has paid off in terms of economic development for Wyoming. Shipping costs of coal on transcontinental railroads has helped Western-mined coal make additional inroads into traditional Illinois coal markets. Transporting Wyoming coal to Georgia is roughly about $\$ 40$ per ton [10]. Energy Information Administration estimates the US will demand additional 100 million tons annually from PRB by 2010 .

The literature clearly shows that transportation is a critical factor in the coal supply chain. The implications of this to the state of Indiana are clear. "Power plants around the country have seen their coal stockpiles dwindle, mainly because of problems with shipping coal out of Wyoming and increasing worldwide demand for energy.” [18] "Once equipped with scrubbers, utilities can buy coal from just about anywhere and still meet the new regulations. Utilities that once burned Indiana coal are expected to return to their roots to take advantage of lower transportation costs, because Indiana is closer than Wyoming.” [13]

While the future appears bright for Indiana coal, lessons can be learned from the current state of the national rail infrastructure. "People call us the Saudi Arabia of coal. But if you don't get it to the power plants, it doesn't matter.” [13] “Otter Tail created a virtual railroad on paper-complete with hypothetical routes, equipment, and customers to show that even a brand-new rail line would be able to serve Otter Tail's coal needs at a lower cost than BNSF.” [10]. This project presents a first step in quantifying Indiana's ability to move coal competitively. 


\section{Chapter 4}

\section{DEMAND and SUPPLY STATES of INDIANA COAL}

This chapter defines the major demand and supply points of coal relative to the power generation industry in the state of Indiana. To narrow the scope of the project, only the ten largest producers and consumers in the power generation industry are analyzed. Additionally, the movement of coal from outside the state will not be considered. Table 1 presents the consumption of coal at the ten largest power plants in the state of Indiana.

Based on this data, three important statistics can be gleaned concerning the state of Indiana coal consumption. Approximately forty percent of the coal consumed by the largest power plants in Indiana is imported. Nearly fifty-one percent of the coal is consumed by Indiana power plants that do not possess scrubbing technology. Finally, nearly thirty-five percent of the coal consumed by Indiana power plants is delivered by barge.

\begin{tabular}{|c|c|c|c|c|c|c|}
\hline Rank & Plant Name & Operator & $\begin{array}{l}\text { Consumption, } \\
000 \text { (tons) ('04 data)** }\end{array}$ & Rail/Barge * & Scrubbed & $\begin{array}{l}\text { \% IN } \\
\text { Coal }\end{array}$ \\
\hline 1 & $\begin{array}{l}\text { Gibson } \\
\text { Station }\end{array}$ & $\begin{array}{l}\text { Duke Energy } \\
\text { Indiana }\end{array}$ & 9,583 & Rail (NS) & Yes & 79 \\
\hline 2 & Rockport & IMP Co, AEP & 9,207 & Barge (NS) & No & 16 \\
\hline 3 & $\begin{array}{l}\text { RM } \\
\text { Schahfer }\end{array}$ & Iosco & 5,026 & Rail (NS) & Yes & 21 \\
\hline 4 & Petersburg & IPL & 5,213 & Rail (ISRR) & Yes & 100 \\
\hline 5 & Clift Creek & Keycorp & 4,470 & Barge & No & 22 \\
\hline 6 & Cayuga & $\begin{array}{l}\text { Duke Energy } \\
\text { Indiana }\end{array}$ & 3,185 & $\begin{array}{l}\text { Rail } \\
\text { (CSX/INDR) }\end{array}$ & No & 64 \\
\hline 7 & Murom & HERE & 2,899 & Rail (INDR) & Yes & 100 \\
\hline 8 & $\begin{array}{l}\text { Tanners } \\
\text { Creek }\end{array}$ & IMP Co, AEP & 2,581 & Barge (CSX) & No & 92 \\
\hline 9 & $\begin{array}{l}\text { Harding } \\
\text { Street }\end{array}$ & $\begin{array}{l}\text { Duke Energy } \\
\text { Indiana }\end{array}$ & 1,877 & Rail (ISRR) & No & 100 \\
\hline 10 & $\begin{array}{l}\text { Wabash } \\
\text { River }\end{array}$ & $\begin{array}{l}\text { Duke Energy } \\
\text { Indiana }\end{array}$ & 2,247 & Rail (INDR) & No & 100 \\
\hline
\end{tabular}

SOURCE: ** 2006 US Coal Industry Map; Global Energy Decisions, LLC.

Table 1

Coal Consumption at Indiana's Ten Largest Power Plants

Table 2 presents the coal production at the ten largest mines in the state of Indiana. Based upon this data, it can be inferred that CSX transports nearly thirty-two percent of the coal mined at the largest mines in Indiana. The remainder of the mined coal is moved by smaller, regionally-based rail companies. 
The mines and power plants presented in this chapter form the basis of the coal supply chain that will be used for the remainder of this project. Rail connections between this set of mines and power plants will be developed using existing rail lines.

\begin{tabular}{|lllll|}
\hline Rank & Mine Name & Mine Operator & $\begin{array}{c}\text { Production, } \\
\mathbf{0 0 0} \text { (tons) '05 }\end{array}$ & Rail Provider * \\
1 & Somerville & Black Beauty Coal Company & 8,144 & ISRR (CSX, NS) \\
2 & Farmersburg & Black Beauty Coal Company & 3,846 & CSX (INDR) \\
3 & Gibson County & Gibson County Coal, LLC & 3,506 & CSX (NS, ISRR) \\
4 & Prosperity & Five Star Mining Inc. & 3,155 & (CSX, ISRR) \\
5 & Francisco & Black Beauty Coal Company & 2,913 & NS (CSX, ISRR) \\
6 & Air Quality & Black Beauty Coal Company & 2,131 & CSX (ISRR) \\
7 & Cannel burg & Solar Sources Inc. & 1,989 & ISRR (CSX) \\
8 & Viking & Black Beauty Coal Company & 1,548 & ISRR (CSX) \\
9 & Cypress Creek & Vigo Coal Co Inc. & 1,288 & NS/ISRR/SCS (CSX) \\
10 & Miller Creek & Black Beauty Coal Company & 1,016 & (CSX, INRR, ISRR) \\
\hline
\end{tabular}

- $\quad$ Rail providers; parenthesis indicate other potential providers within a 15 mile radius SOURCE: 2006; Indiana Coal Council, Inc.

NOTE: Rail Abbreviations:

CSX: CSX Transportation

NS: Norfolk Southern Corporation

INDR: The Indiana Rail Road

ISRR: Indiana Southern Railroad

SCS: Squaw Creek Southern

Table 2

Coal Production at Indiana’s Ten Largest Coal Mines 


\section{Chapter 5}

\section{RAIL TRANSPORTATION of INDIANA COAL}

This chapter describes the rail infrastructure that currently exists in the state of Indiana that connects the set of coalmines and power plants defined in Chapter 4.

The movement of commodities over a rail system is complex due to the structure of the rail ownership system in the United States. Consolidation of rail companies over the years has created a small number of mega-carriers who operate large multi-state networks. These are referred to as Class 1 railroads and include CSX, Norfolk Southern, BNSF, etc. The remainder of the railroads are smaller, many of which operate less than ten miles of total track. Thus, the development of point-to-point rail connections is a complex process that is analogous to the interstate highway system or a fiber optic cable network. Large mega-railroads such as the CSX move large volumes of cargo efficiently along Class 1 rail between distribution points across the United States. The cargo is then broken down into loads for specific industry or distribution sites and is often moved by small regional railroads over local tracks. This type of system is referred to as the 'last mile’ problem.

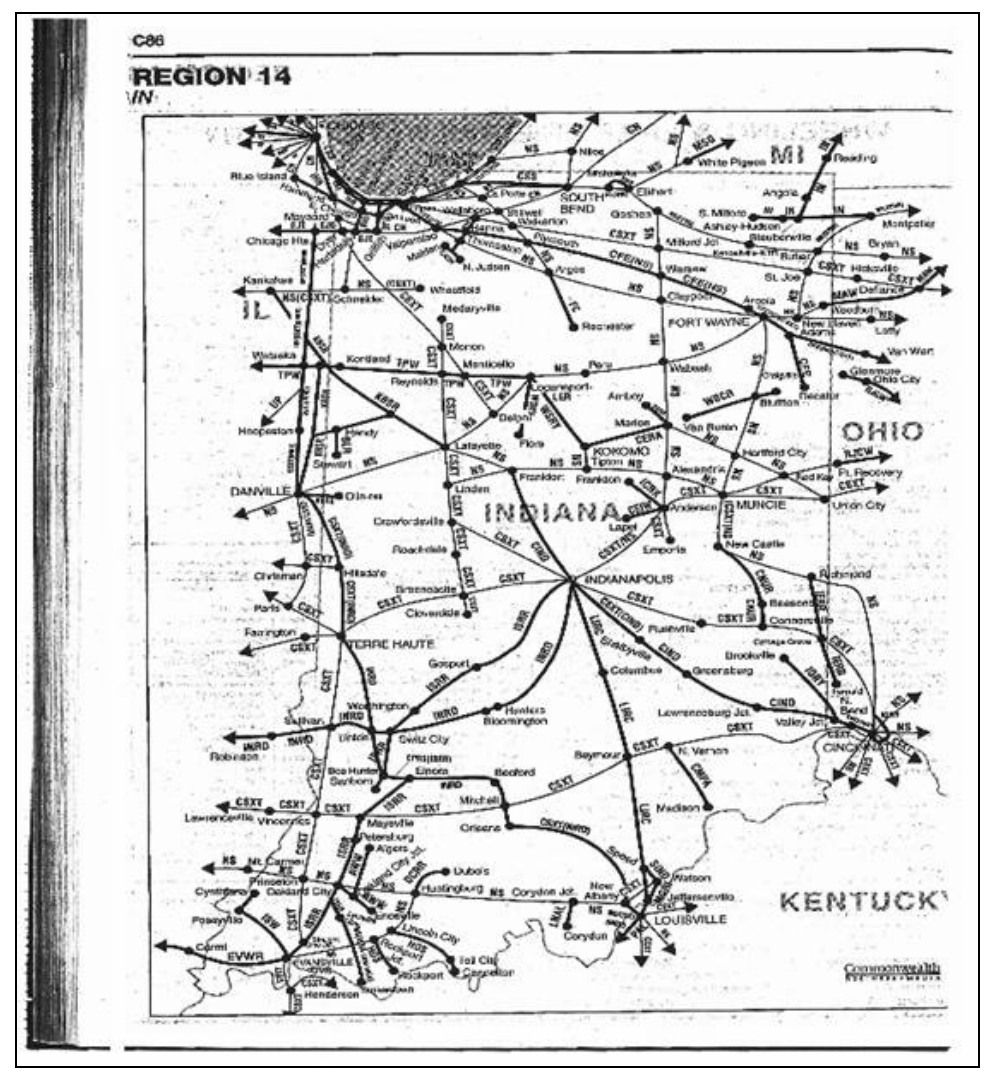

Figure 3

Indiana Rail Infrastructure 
Figure 3 shows the current rail infrastructure in the state of Indiana. Noticeably absent are north-south routes spanning the State.

The operation of a railroad is dependent on many factors, including route capacity, track condition, operating rules, equipment, terminal operations, etc. To characterize the Indiana coal transportation infrastructure, a set of timetables that define significant rail routes within the state were developed. Example timetables can be found in figures 1 and 10. Within the timetable are several attributes that contribute to the coal transportation potential within Indiana. The Number column denotes how many tracks are available on the mainline. The Class column is a universally accepted, macro descriptor based upon factors such as welded versus jointed track, curvature, grade, maximum speed, signaling, etc. The class descriptor ranges from a value of one, which denotes ideal conditions, to six, which denotes poor conditions. Table 3 presents rail class definitions.

CLASS:

1: 136 lbs per yard welded rail; straight track; trackside signaling

2: 136 lbs per yard welded rail; track with high curvature; trackside signaling

3: 136 lbs per yard welded rail; straight track; no signaling

4: 136 lbs per yard welded rail; track with high curvature; no signalling

5: 136 lbs per yard jointed rail; straight track; no signaling

6: $136 \mathrm{lbs}$ per yard jointed rail; track with high curvature; no signaling

7: 136 lbs per yard welded rail; straight track; trackside signaling, electrified

\begin{tabular}{l}
\begin{tabular}{|c|c|c|c|c|}
\hline \multicolumn{5}{|c|}{ TRACK STRUCTURE } \\
\hline Classification & Rail* & Tangent & Signaling & Notation \\
\hline 1 & welded & straight & yes & - \\
\hline 2 & welded & curved & yes & - \\
\hline 3 & welded & straight & no & - \\
\hline 4 & welded & curved & no & -- \\
\hline 5 & jointed & straight & no & - \\
\hline 6 & jointed & curved & no & - \\
\hline 7 & welded & straight & yes & Electrified \\
\hline
\end{tabular} \\
*: All rail 136 lbs per yard \\
\hline
\end{tabular}

Table 3

Rail Class Definition

Each link in the timetables is given a class value. Using this value, we can generate a statistic that quantifies the rail infrastructure relative to a given rail route, coal mine, or power plant. Figure 4 graphically displays the average class condition that exists between each of the mines and power plants. This value is calculated as the weighted average of class and distance. For example, the rail conditions for the route defined by the timetable between the Rockport power plant and the Somerville mine is approximately 4.75. This denotes unfavorable conditions for moving large amounts of coal. Conversely, the rail conditions between the Gibson power plant and the Somerville mine are calculated to 1.0, which denotes ideal conditions. If the class variable is 
analyzed according to power plant and mine, as illustrated in Figures 5 and 6, we see that more variation exists from the power plant perspective.

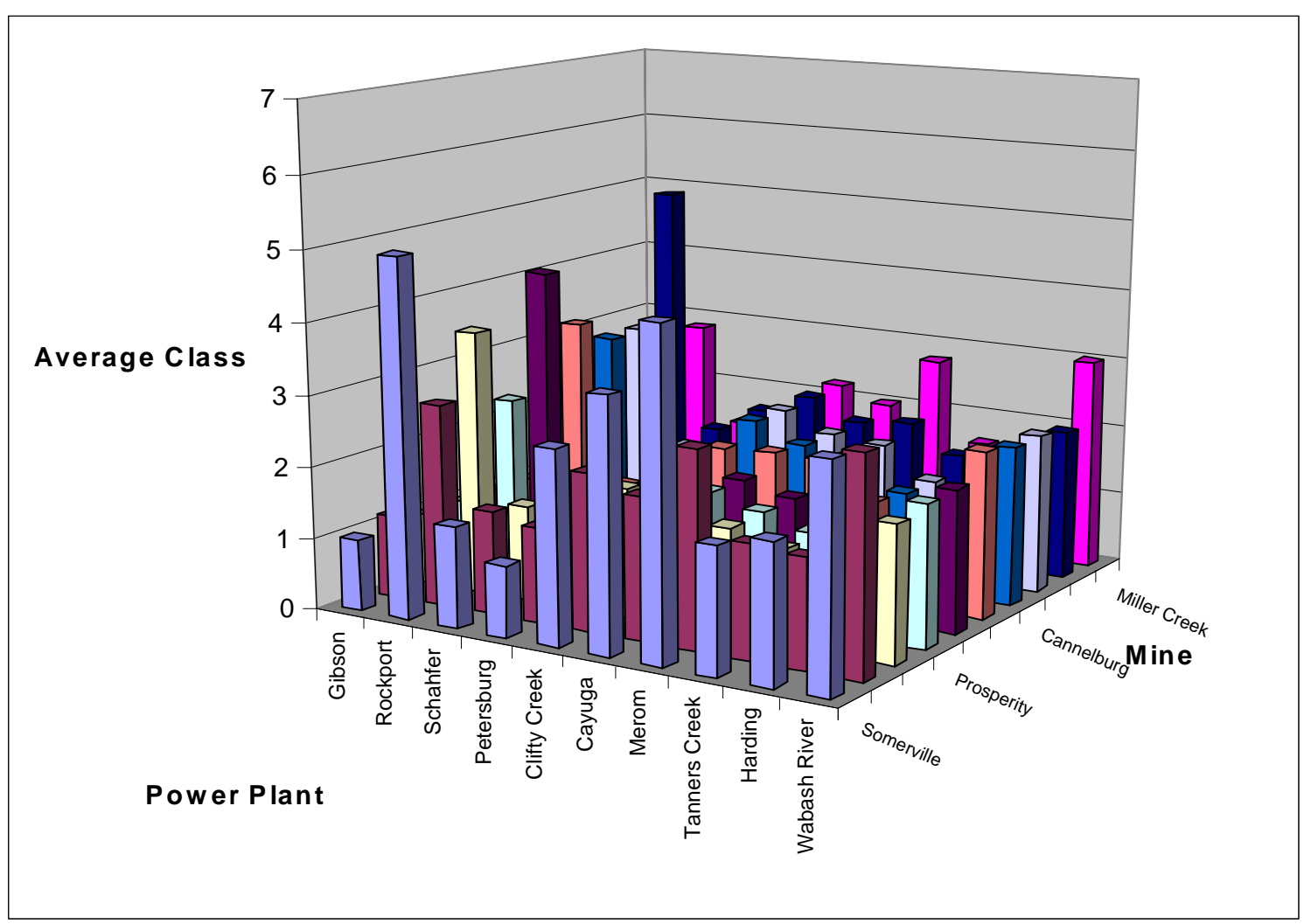

Figure 4

Average Rail Class Summary

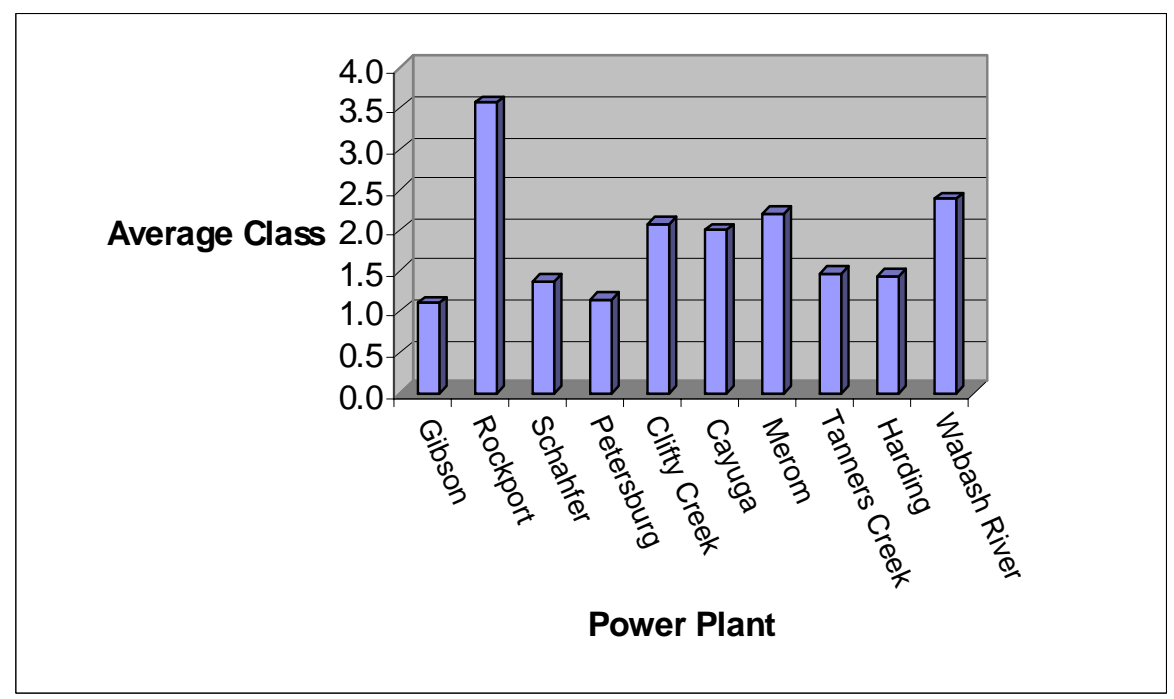

Figure 5

Average Rail Class by Power Plant 


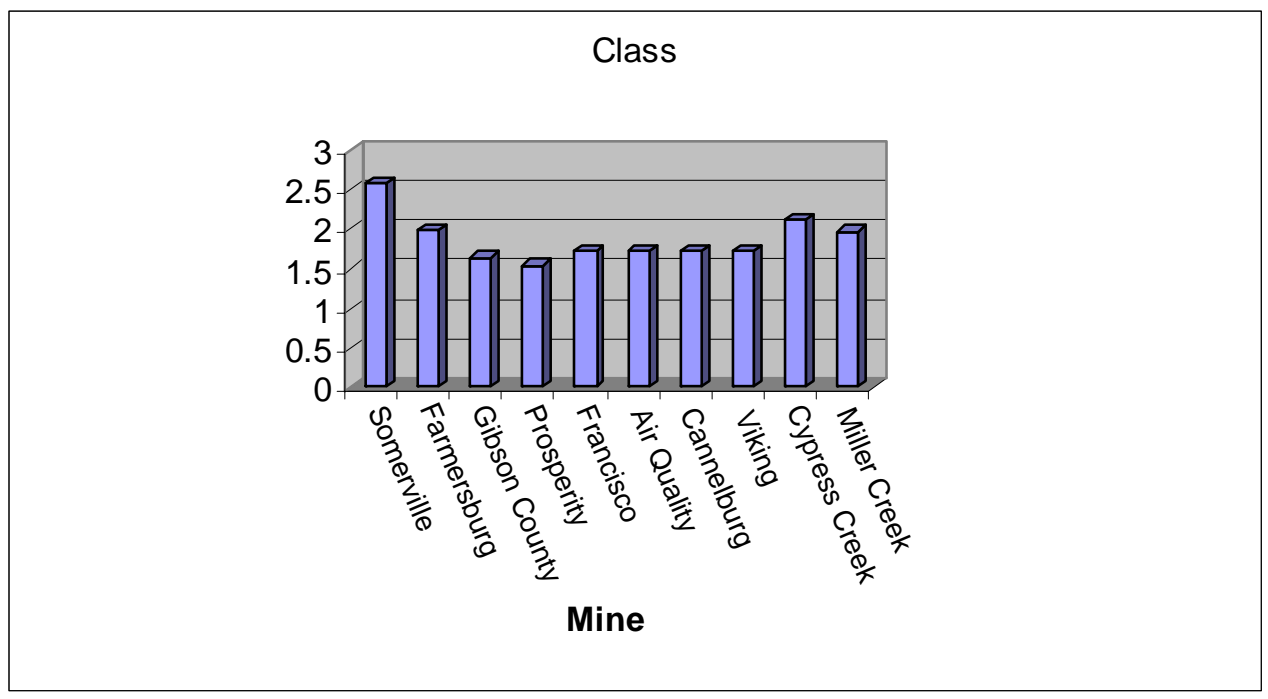

Figure 6

Average Rail Class by Mine

Directly related to class is the speed that can be attained over a section of rail. Figure 7 graphically displays the average speed that can be attained between each of the mines and power plants. This value is calculated as the weighted average of speed and distance. For example, the average speed for the route defined by the timetable between the Rockport power plant and the Somerville mine is approximately twenty miles per hour. Again, this denotes unfavorable conditions for moving large amounts of coal.

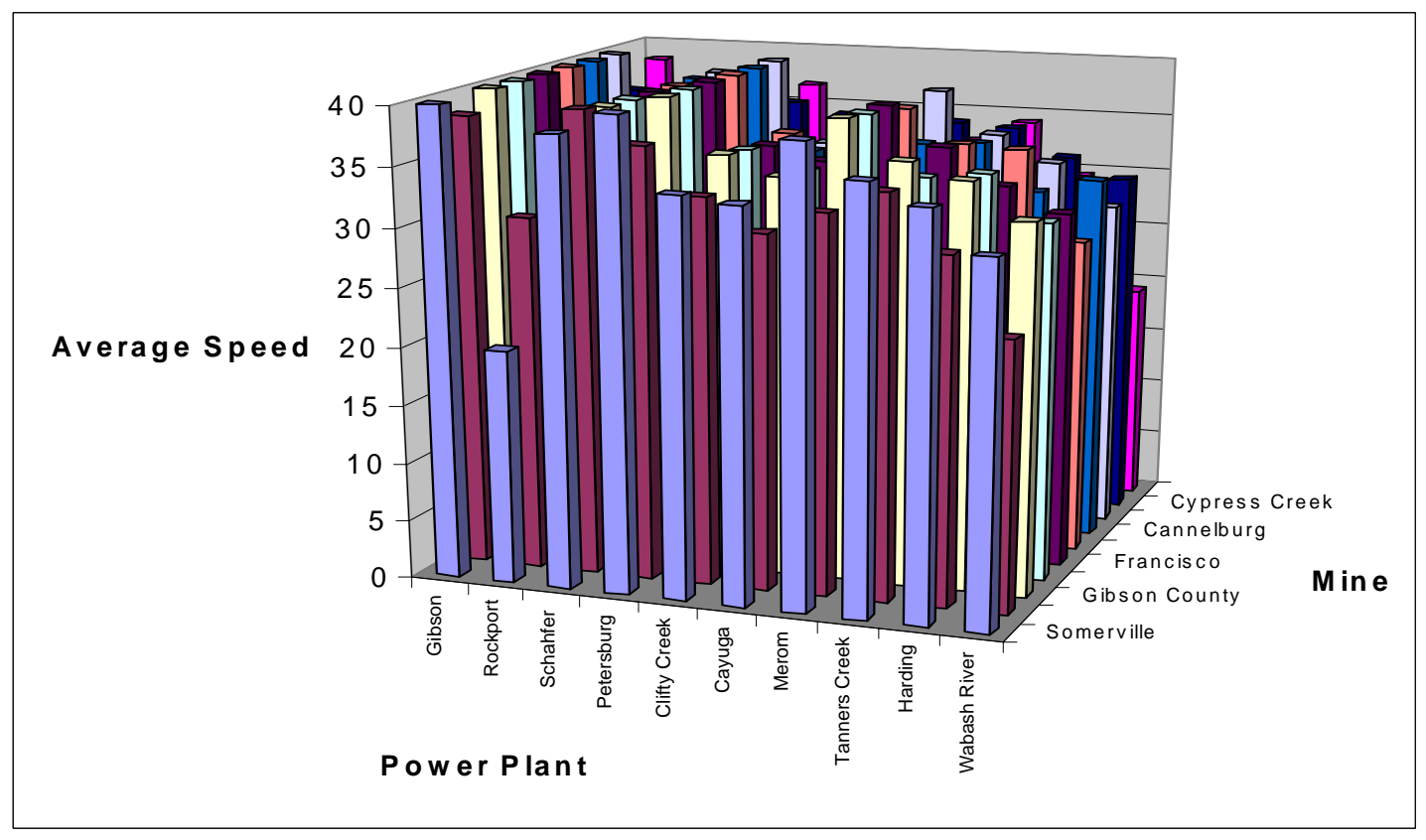

Figure 7

Average Rail Speed Summary 
Conversely, the average speed between the Gibson power plant and the Somerville mine is approximately forty miles per hour, which suggests a large productivity difference for the railroad and the power plant. If the speed variable is analyzed according to power plant and mine, as illustrated in Figures 8 and 9, we see that the variability is roughly the same from either perspective.

Through the use of the timetables constructed as the basis of this project, one can easily quantify the rail infrastructure of Indiana for any scenario of interest. From the limited subset of mines and power plants, one can see that significant variability is present in the Indiana rail infrastructure. This suggests that point-to-point rail routes between suppliers and consumers of coal were well thought out and that switching costs may be high. This judicious development of the rail infrastructure can severely limit the ability of mines and power plants to selectively employ spot market pricing strategies for coal.

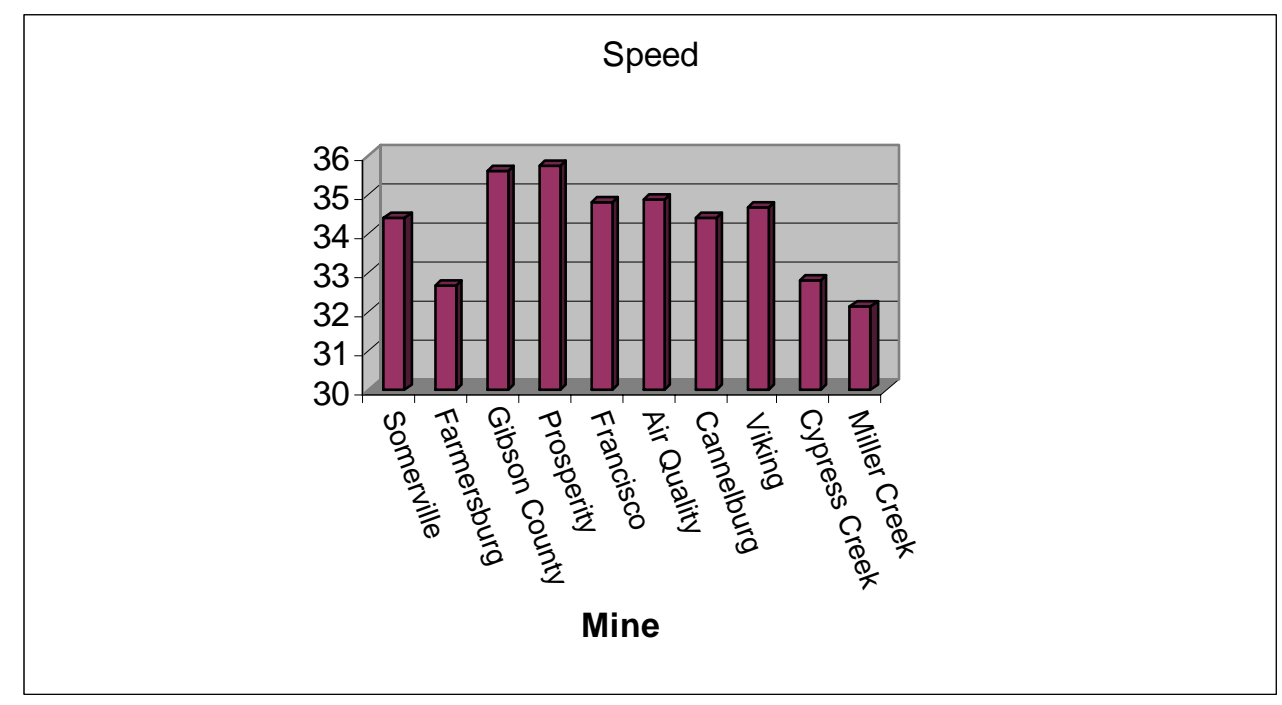

Figure 8

Average Rail Speed by Mine 
A Prescriptive Analysis of the Indiana Coal Transportation Infrastructure Brady, Pfitzer

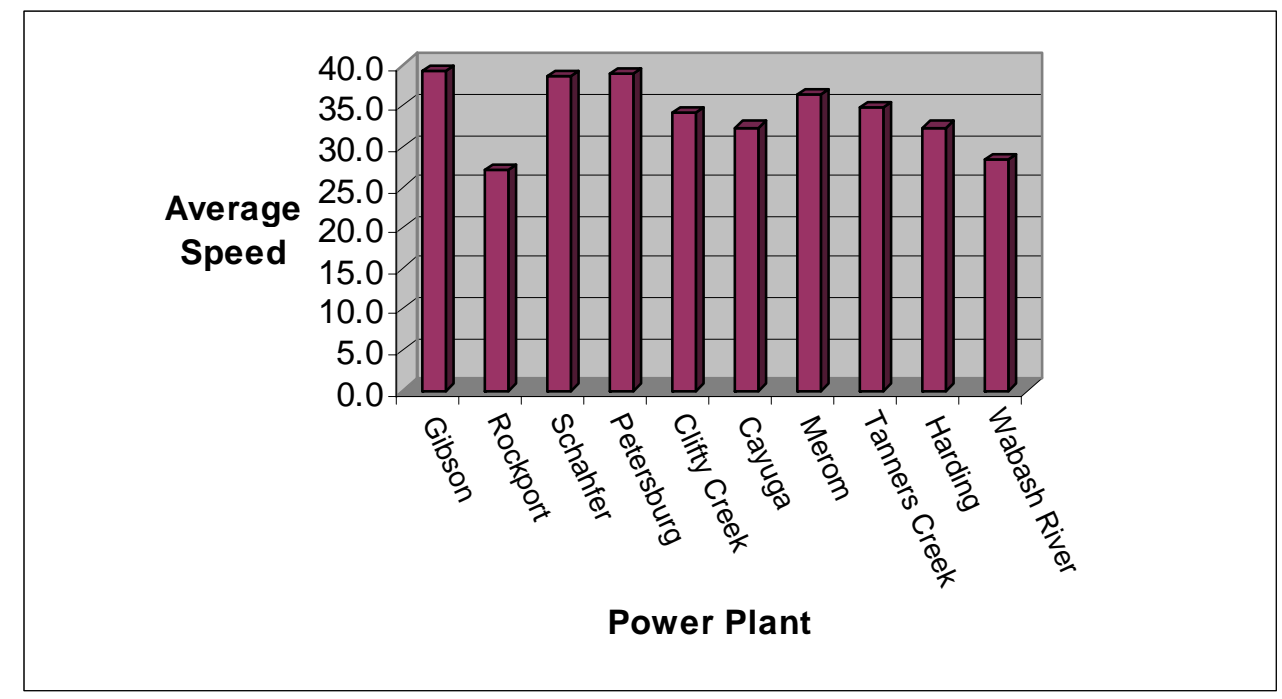

Figure 9

Average Rail Speed by Power Plant 


\section{Chapter 6}

\section{OPERATIONAL ASPECTS of COAL TRANSPORTATION}

This chapter describes the operational aspects of a typical power plant coal supply chain. Power plants operate in a highly variable environment. The amount of power demanded by industry and consumers is dependent on numerous factors. Further compounding power plant operation is the fact that electricity cannot be inventoried. Thus, a typical power plant must be must be capable of quick adjustment to the demand requirements of its service area.

The practice of the stocking of coal at a power plant follows standard inventory replenishment models [24]. These models are either order point or time period based. Order point-based inventory policy states that when the current inventory level falls below a specified threshold value, an order is placed for additional inventory. Time period-based inventory policy states that the inventory level is examined at discrete time intervals and an order is placed for an amount equal to a target level minus the current level. Both models attempt to strike a balance between the inventory investment by the company and the probability of stock-out situations for the customer.

Regardless of which method is employed, there are five parameters that define inventory replenishment models. These parameters include:

- Maximum Inventory Level: The maximum amount of inventory that is capable of being stored by the power plant

- Consumption Rate: The average rate that inventory is consumed

- Lead Time: The time it takes to replenish a given amount of inventory

- Order Quantity: The amount of inventory that can be replenished in one instance

- Safety Stock: The minimum amount of inventory on hand at all times

The critical parameter for inventory replenishment models is lead time. If inventory can be replenished quickly and reliably, then the amount that needs to be stocked can be minimized. The move to a just-in-time paradigm in the manufacturing sector has been achieved primarily due to the increased reliability and capability of the logistics industry to support more frequent replenishment. As the logistics industry has improved, manufacturers have significantly reduced their inventories, which frees up cash and improves financial position..

The significance of the rail infrastructure constraints and variability detailed in Chapter 3 manifest themselves in the operational aspects of power plants. As long as variability in the lead time of coal transportation exists, power plants will be forced to hold extra coal 
inventories as a hedge against delivery issues. This increases the cost of power generation to everyone.

To illustrate the operational aspects of power plant, consider the Schahfer Generating Station in Wheatfield, Indiana. This plant consumed over five million tons of coal in 2006. This equates to a daily average of nearly fourteen thousand tons per day. To illustrate the variability in operations, the station's coal handling department bunkered more than twenty-one thousand tons of coal on July 26, 2006 [27]. As a hedge against demand and lead time variability, it is estimated that power plants keep a forty day supply of coal on hand. Using a benchmark price of \$35 per ton delivered, the investment in coal alone at Schahfer is more than nineteen million dollars. Dell Computer, Inc. has demonstrated that they run their assembly plants with four hours of inventory, in part due to efficiencies that exist in the trucking transportation infrastructure [24]. Comparable performance in the Indiana rail infrastructure would provide significant economic advantage to industries dependent on rail.

The order quantity that can be used in power plant operations is dependent on train capacities. Train capacities are dependent on the track infrastructure. Thus, it is desirable to have a Class 1 route between coalmine and power plant. Current coal unit trains have capacities of approximately 12,500 tons. To maintain a forty-day coal supply from PRB, Schahfer would need to have two dedicated unit trains averaging forty miles per hour.

This chapter has shown that the operational aspects of power plants depend greatly on the efficiency of the rail infrastructure that serves them. Until the rail infrastructure demonstrates efficiency and variability improvement, power plants will be unable to achieve significant cash flow savings through inventory reduction similar to the manufacturing industry. 


\section{Chapter 7}

\section{COAL TRANSPORTATION SIMULATION MODEL}

This chapter describes the concept and development of a computer simulation model of the Indiana coal transportation infrastructure. The simulated environment will allow what-if capability to demonstrate performance aspects of the Indiana coal transportation infrastructure across a number of current and proposed scenarios.

The efficient movement of goods through a rail transportation infrastructure is subject to numerous external factors. These factors can be characterized by two attributes: process variation and dependency. Process variation refers to the deviation of individual values around an average. It is present in any activity and presents numerous challenges to efficiency. The current United States rail infrastructure includes many bottlenecks that can add significant incremental time to projected 'average' transport times. Dependency refers to the concept that any supply chain is composed of a number of links. Ownership of the links affects rail movement. It is difficult to find direct point to point movements in the United States rail system that do not involve multiple owners. Movement of trains through a shared rail network is defined and accomplished through the use of timetables. The interdependencies of the links determine overall efficiency of the supply chain. The operation of a railroad is dependent on many factors, including route capacity, track condition, operating rules, equipment, and terminal operations. Timetables are fully described in Chapter 2.

Simulation modeling is an ideal technology for the analysis of rail operations since it can accurately portray operations that include significant variability. Simulation models can effectively represent elements such as track interference, equipment and weather delays, acceleration and speed variability, and normal chaos conditions that render rail capacity and performance estimation difficult to predict. Numerous papers have been published over the years in venues such as the Winter Simulation Conference proceedings that have demonstrated the effectiveness of simulation in rail planning and analysis [14].

The timetable concept forms the basis of the simulation model developed for this project. Trains are routed between locations according to attributes defined by the timetables. Speeds for the trains are dependent upon the class rating for each link in the route. Specific logic for connections and interlocks are also based upon information contained in the timetable.

The construction of a scenario involves defining source and sink points. These are locations that require rail service. Service demand is generated either by standard inventory replenishment policy or discrete time logic in which events occur at defined intervals. The route for the train(s) that serve the destinations is defined by the timetables. Each timetable consists of a series of links, which are defined as a segment of rail between two stations. 
Table 4 lists the general parameters that are present in each simulation scenario. The Type column indicates whether the parameter is a global or local variable. Global variables are applied to every link in the timetable routings. Local variables are specific to the link they are associated with. The Location column identifies the specific area in the simulation scenario where the parameter is applied.

\begin{tabular}{|l|l|l|}
\hline \multicolumn{1}{|c|}{ Parameter } & \multicolumn{1}{c|}{ Type } & \multicolumn{1}{c|}{ Location } \\
\hline Speed Factor & Global & All Rail Links \\
\hline Weather Factor & Global & All Rail Links \\
\hline Mechanical Delay & Local & Specific Rail Link \\
\hline Congestion Delay & Local & Specific Rail Link \\
\hline Station Delay & Local & Specific Rail Link \\
\hline Train Length & Local & Specific Train \\
\hline Car Size & Global & All Trains \\
\hline Days of Supply & Local & Specific Power Plant \\
\hline \multicolumn{3}{|c|}{ Table 4} \\
\hline
\end{tabular}

Generic Simulation Model Parameters

- Speed Factor is a random variable that is applied to calculation of train speed

- Weather Factor is a random variable that is applied to logic between links

- Mechanical Delay is a random variable that is applied to logic between links

- Congestion Delay is a random variable that is applied to logic between links

- Station Delay is a random variable that is applied to logic between links

- Train Length is a user supplied value that denotes the number of cars in a train

- Car Size is a user-supplied value that defines the capacity of each car

- Days of Supply is a user-supplied value that defines the target coal inventory at a power plant

As the simulation model progresses, trains move from station-to-station via links. Prior to entering a link, the appropriate station logic is applied. This allows very detailed routing logic to be included, which greatly increases the precision and accuracy of the results obtained.

Triangular distributions are widely used in simulation modeling to represent time parameter items that are difficult to capture or cannot be fitted to traditional distributions such as the normal or erlang [14]. All of the time dependent parameters for the simulation model developed for this project use triangular distributions to generate activity durations. Table 5 lists the default values for the major delay parameters used in the model. 


\begin{tabular}{|l|l|l|l|}
\hline \multicolumn{1}{|c|}{ Parameter } & Minimum & Most Likely & Maximum \\
\hline Mechanical Delay & .5 hours & 3 hours & 18 hours \\
\hline Congestion Delay & .1 hours & 3 hours & 8 hours \\
\hline Station Delay & .1 hours & .5 hours & 1 hour \\
\hline
\end{tabular}

Table 5

Simulation Model Delay Parameter Values

Table 6 lists the probability values for given events in each scenario.

\begin{tabular}{|l|l|}
\hline \multicolumn{1}{|c|}{ Parameter } & Probability of Occurrence \\
\hline Congestion Delay & .005 percent \\
\hline Mechanical Delay & .07 percent \\
\hline Station Delay & .025 percent \\
\hline \multicolumn{2}{|c|}{ Table 6} \\
\multicolumn{2}{|c|}{ Simulation Model Delay Probability Values }
\end{tabular}

For power plant operations, annual coal consumption is converted to a daily value. This value is then adjusted to one of the conditions based on the values shown in Table 7.

\begin{tabular}{|l|c|l|l|}
\hline \multicolumn{1}{|c|}{ Parameter } & Minimum & Most Likely & Maximum \\
\hline Daily Demand State & 20 percent & 50 percent & 30 percent \\
\hline Daily Demand Multiplier & .45 & 1.00 & 1.50 \\
\hline
\end{tabular}

Table 7

Simulation Model Power Plant Coal Demand Parameter Values

Standard output metrics are provided by the simulation model. These metrics include utilization values for trains, inventory levels at power plants, and train journey times. 


\section{Chapter 8}

\section{SCENARIO 1: FRANCISCO MINE to WABASH RIVER POWER STATION}

This chapter presents the details of a simple analysis using the simulation model and a timetable for a select mine and power plant. The Francisco mine produced nearly 2.1 million tons in 2006. The Wabash River Power Station consumed nearly 2.2 million tons. There is a direct class $1 \mathrm{CSX}$ rail line between the mine and the power plant, but it is highly utilized with intermodal and general freight traffic. Thus, adding additional coal traffic is not desirable for CSX. Thus, coal trains serving the power plant use secondary track rated at class 1 and 5 that pass through numerous towns. This contributes to slower average train velocity, which greatly increases the coal inventory requirements for the power plant and train resource time for the railroad. The objective of this scenario is to investigate the impact of train length and car size on coal inventory position at the power plant.

\begin{tabular}{|c|c|c|c|c|c|c|c|}
\hline \multirow[t]{2}{*}{ STATION } & \multirow[t]{2}{*}{ MILEAGE } & \multicolumn{4}{|c|}{ TRACK } & \multirow[t]{2}{*}{ NOTATIONS } & \multirow{2}{*}{$\begin{array}{c}\text { OWNERS } \\
\text { PRESENT AT } \\
\text { INTERLOCKS }\end{array}$} \\
\hline & & OWNER & NUMBER & CLASS & SPEED & & \\
\hline \multicolumn{8}{|c|}{ READ DOWNWARD FOR NORTHBOUND } \\
\hline FRANCISCO & 0.00 & NS & 1 & $\overline{-}$ & 40 & & \\
\hline $\begin{array}{l}\text { OAKLAND } \\
\text { CITY }\end{array}$ & 5.75 & $\begin{array}{l}\text { NS, } \\
\text { ISRR }\end{array}$ & 1 & - & 25 & A & NS, ISRR \\
\hline ASHBY YARD & 16.25 & ISRR & 1 & - & 25 & $\mathrm{~B}, \mathrm{E}, \mathrm{Y}$ & \\
\hline PETERSBURG & 17.75 & ISRR & 1 & - & 25 & & \\
\hline MAYSVILLE & 33.25 & ISRR & 1 & - & 25 & & \\
\hline CHAPPEL & 34.75 & $\begin{array}{l}\text { ISRR, } \\
\text { INRD }\end{array}$ & 1 & - & 25 & M & ISRR, CSXT \\
\hline ELNORA & 53.75 & INRD & 1 & - & 40 & A & ISRR, INRD \\
\hline BEEHUNTER & 59.75 & INRD & 1 & - & 40 & A & INRD, ISRR \\
\hline LINTON & 65.75 & INRD & 1 & - & 20 & A & INRD \\
\hline LATTA & 73.75 & INRD & 1 & - & 20 & $\mathrm{~B}, \mathrm{~T}, \mathrm{Y}$ & \\
\hline KELLER & 78.75 & INRD & 1 & - & 40 & $\mathrm{P}$ & \\
\hline SPRING HILL & 96.75 & INRD & 1 & - & 25 & $M$ & CSXT \\
\hline BELT JCT & 98.00 & INRD & 1 & - & 25 & $\mathrm{M}, \mathrm{T}$ & CSXT \\
\hline VAN YARD & 103.00 & INRD & 1 & - & 25 & $B, Y$ & \\
\hline PRESTON & 104.25 & INRD & 1 & - & 10 & $M$ & CSXT \\
\hline DEWEY & 104.75 & INRD & 1 & - & 10 & $M$ & CSXT (INRD) \\
\hline $\begin{array}{l}\text { WABASH } \\
\text { RIVER POWER } \\
\text { PLANT }\end{array}$ & 109.25 & INRD & 1 & - & 10 & & \\
\hline & & $R E$ & UPWARD & $\overline{\text { R SOUT }}$ & BOUND & & \\
\hline
\end{tabular}

Figure 10

Scenario 1 Route Timetable 
Rail transportation between the mine and the power plant is accomplished according to the timetable shown in Figure 10. The model contains specific logic for each station in the timetable according to the notation and interlock columns. Train speed, with appropriate random factors are also defined by the timetable on a station-by-station basis. The computer simulation animation screen for this scenario is shown in Figure 11. Coal is delivered to the plant according to a classic order point inventory replenishment scheme. Appropriate randomness factors and the standard operational parameters defined in Chapter 7 have been applied to assure realistic results

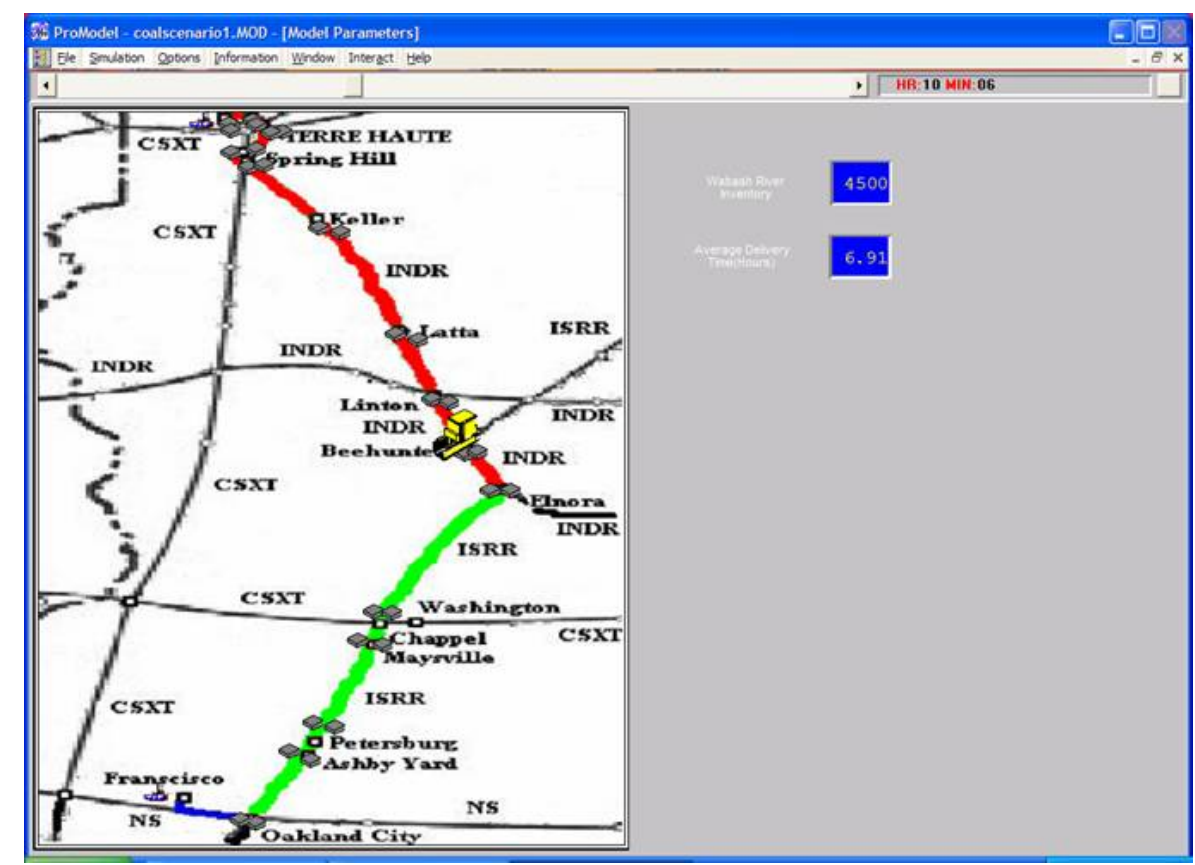

Figure 11

Scenario 1 Animation Screen

A factorial design experiment consisting of three factors and three levels was used to demonstrate the effects of rail class infrastructure on the operational aspects of power plant coal usage. The factors and associated levels are shown in Table 8. Performance measures used included locomotive utilization and tons delivered per train hour. Train length and weight of the coal cars are directly related to the class category of the rail route. In this scenario, train lengths are limited to fifty cars due to the sections of class five track that exist in the route. Results of the simulation indicated that it was infeasible to carry less than a twenty-day supply of coal due to the inability of the rail connection throughput to meet this coal inventory requirement. 


\begin{tabular}{|c|c|c|c|c|}
\hline Days Supply & Train Length & Car Size & Loco Util & TTH \\
\hline 15 & 50 & 186000 & 42 & $\mathbf{5 1 8}$ \\
\hline 15 & 110 & 186000 & 50 & 1149 \\
\hline 15 & 125 & 186000 & 50 & 1329 \\
\hline 15 & 50 & 236000 & 87 & 667 \\
\hline 15 & 110 & 236000 & 39 & 1438 \\
\hline 15 & 125 & 236000 & 34 & 1637 \\
\hline 15 & 50 & 286000 & 71 & 811 \\
\hline 15 & 110 & 286000 & 32 & 1773 \\
\hline 15 & 125 & 286000 & 28 & 2047 \\
\hline 40 & 50 & 186000 & 80 & 534 \\
\hline 40 & 110 & 186000 & 44 & 1172 \\
\hline 40 & 125 & 186000 & 39 & 1351 \\
\hline 40 & 50 & 236000 & 73 & 684 \\
\hline 40 & 110 & 236000 & 35 & 1525 \\
\hline 40 & 125 & 236000 & 31 & 1680 \\
\hline 40 & 50 & 286000 & 64 & 816 \\
\hline 40 & 110 & 286000 & 28 & 1794 \\
\hline 40 & 125 & 286000 & 25 & 2066 \\
\hline
\end{tabular}

Table 8

Scenario 1 Factorial Design 


\section{Chapter 9}

\section{SCENARIO 2: VINCENNES RAILROAD RELOCATION}

This chapter presents the details of an analysis involving vehicular traffic using the simulation model of the Indiana rail infrastructure. The city of Vincennes is located in southern Indiana. Three major rail lines cross through the city. Over seventy trains per day, including many unit coal trains move through the city across forty-seven crossings. The movement of trains through the city cause significant productivity and safety issues to both citizens and the railroads. The city is in the process of securing funding to remove the rail lines from the inner city and route them into a corridor that will run outside the city limits.

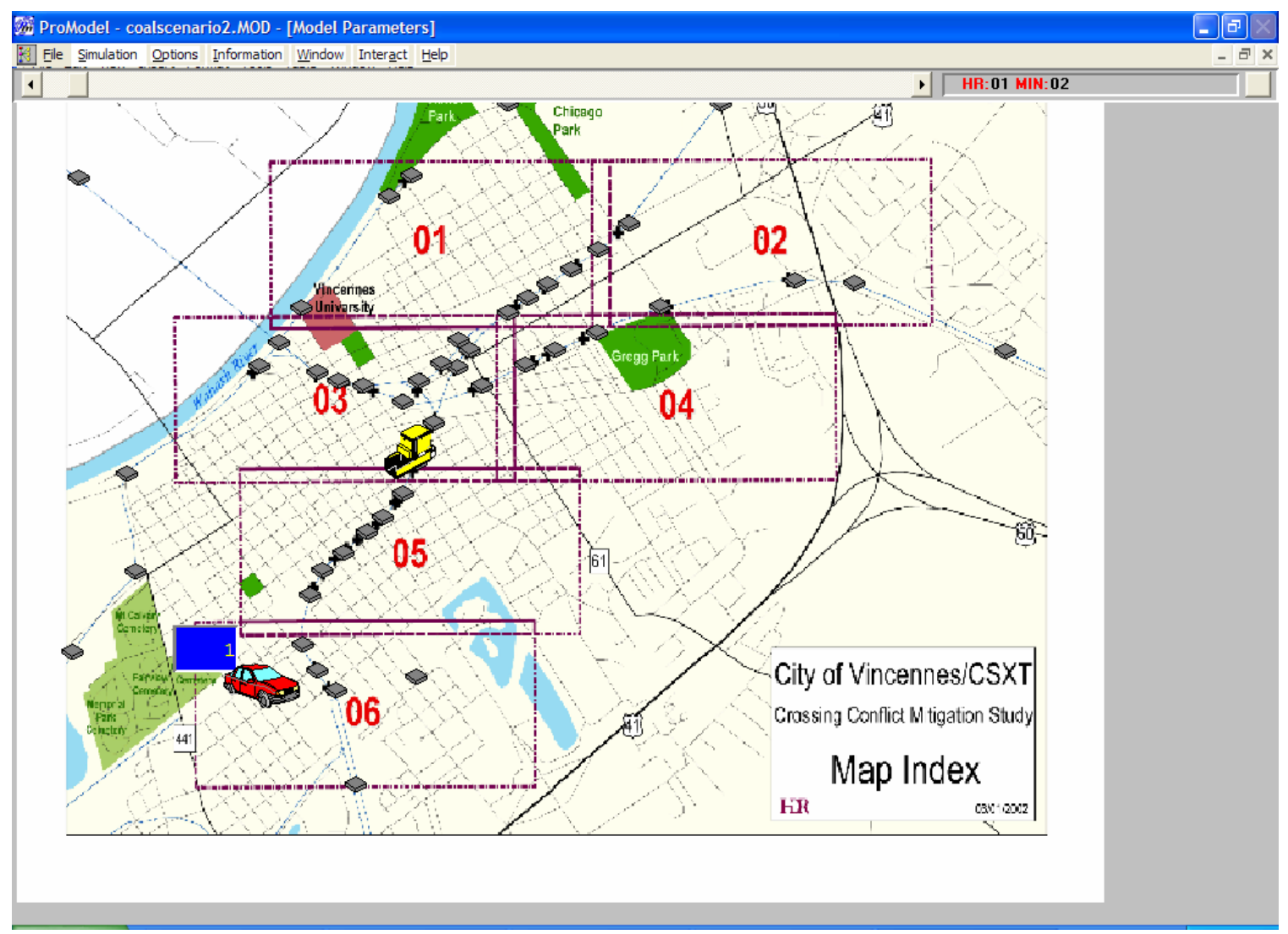

Figure 12

Scenario 2 Animation Screen

Preliminary engineering studies have been performed to define alternative corridor locations and the associated benefits of each alternative [5]. The objective of the simulation study was to verify benefits identified in the engineering studies and provide more detailed information as to where and when the benefits occur. The simulation model explicitly modeled the major train thoroughfares through the city and each specific 
street crossing. Crossings were segregated into zones to facilitate a phased approach to the project. Figure 12 presents the animation screen for the simulation.

All trains passing through the city were modeled. Only the vehicular traffic in zone six was modeled. Three crossings exist in zone six with AADT (Average Annual Daily Traffic) volumes of 500,250, and 1000 respectively. The distribution of these arrivals throughout the day was based on the percentages shown in Table 9.

\begin{tabular}{|c|c|c|c|}
\hline Hour & \% Arrivals & Hour & \% Arrivals \\
\hline 0 & 1 & 12 & 15 \\
\hline 1 & .1 & 13 & 2 \\
\hline 2 & .1 & 14 & 2 \\
\hline 3 & .3 & 15 & 2 \\
\hline 4 & .5 & 16 & 2 \\
\hline 5 & 3 & 17 & 12 \\
\hline 6 & 15 & 18 & 15 \\
\hline 7 & 15 & 19 & 7 \\
\hline 8 & 2 & 20 & 1 \\
\hline 9 & 2 & 21 & .3 \\
\hline 10 & 2 & 22 & .2 \\
\hline 11 & 15 & 23 & .2 \\
\hline
\end{tabular}

Table 9

Scenario 2 Vehicle Arrival Distribution

Performance metrics of interest included vehicle wait and blocking times. Results from the model indicate that the average time blocked at these crossings was approximately 24.5 minutes. On an annual basis, this equates to productivity loss of nearly one hundred thirty people. If the amount of fuel burned while waiting is factored in, clearly there is a large social cost incurred by having high-density rail lines running through a large city. There is also a productivity cost for the railroad by operating in this environment due to reduced train velocities.

The figures derived from the simulation modeling approach differ slightly from those presented in the preliminary engineering reports. By using simulation, the dynamic effects of train crossing interference can be captured at the vehicle level, thus providing a much more accurate estimate of waiting times. 


\section{Chapter 10}

\section{SCENARIO 3: FARMERSBURG MINE to SCHAHFER POWER PLANT}

In this chapter, we use the simulation model to analyze a hypothetical scenario concerning south to north coal movement in Indiana. Consider the movement of coal from the Farmersburg mine to the Schahfer power plant. Each of these entities is in the top ten in terms of coal tonnage in Indiana. The Farmersburg mine produces approximately 3.85 million tons per year while the Schahfer power plant consumes approximately 5.03 million tons. Schahfer also burns predominately non-Indiana coal, although it does possess scrubbing technology. Although Schahfer consumes more coal than Farmersburg produces, this scenario is used to demonstrate the difficulties in moving coal from southern to northern Indiana.

The objectives for this scenario include the determination of the number of unit trains needed and the amount of train interference to be expected.

The timetable for train movement between Farmersburg and Schahfer is shown in Table 13. Specific logic for each station in the timetable according to the notation and interlock columns are included in the simulation. Train speed, with appropriate random factors are also defined by the timetable on a station-by-station basis. The computer simulation animation screen for this scenario is shown in Figure 14. Coal is delivered to the plant according to a classic order point inventory replenishment scheme with a days-of-supply target. Appropriate randomness factors along with the standard operational parameters defined in Chapter 7 have been applied to assure realistic results. The route between Farmersburg and Schahfer is partitioned into four zones. Before a train can enter a zone, it must obtain the track right-of-way. 
SCHEDULE 2.3: FARMERSBURG MINE - RM SCHAHFER POWER STATION

\begin{tabular}{|c|c|c|c|c|c|c|}
\hline \multirow[t]{2}{*}{ STAUION } & \multirow[t]{2}{*}{ MILEATEE } & \multicolumn{4}{|c|}{ IREACIK } & \multirow[t]{2}{*}{ NOIATIONS } \\
\hline & & OWNER & RUMBER & CLASS & SPEED & \\
\hline \multicolumn{7}{|c|}{ READ DOWWWARD FOR WORTHBOUWD } \\
\hline RELUER & 0.0 & INACiR & 1 & 3 & $40^{-}$ & P,T \\
\hline LATTA & 5.0 & INCR & 1 & 3 & 20 & B,E,T,Y \\
\hline LINTON & 9.0 & INCR & 1 & 3 & 20 & A \\
\hline SWITZCITY & 14.5 & INCR & $T$ & $T$ & 40 & $\mathbf{A}$ \\
\hline WORTHINGGTON & 21.5 & INCR & 1 & 1 & 40 & P,Y \\
\hline SPENCER & 40.0 & INCR & 1 & 2 & 25 & - \\
\hline WHITAKER & 53.0 & INCR & 1 & 1 & 40 & $\overline{\mathbf{P}}$ \\
\hline MARTINSVILE & 63.0 & INCR & 1 & 1 & 40 & - \\
\hline MOORESVLLE & 77.0 & INCR & 1 & 1 & 40 & - \\
\hline CP HOLT & 89.5 & $\mathbb{I N}$ INCR & 1 & 1 & 10 & $\bar{T}$ \\
\hline CP HUNT & 70325 & $\mathbb{T N}$ & 7 & 2 & 10 & - \\
\hline CP CLERMONT & 106.25 & $\mathbb{I N}$ & 1 & 2 & 20 & H \\
\hline BROWNSBURG & 110.0 & $\mathbb{I N}$ & $\overline{1}$ & $\overline{1}$ & 40 & $\overline{-}$ \\
\hline CRAWFORSVIUE & 140.5 & $\mathbb{I N}$ & $\overline{1}$ & $\overline{1}$ & 40 & ++ \\
\hline LINDEN & 149.5 & $\mathbb{I N}$ & 1 & 1 & 40 & L, P \\
\hline LAFAYETTE JCT & 164.5 & $\mathbb{I N}$ & 1 & 1 & 10 & $\mathbf{M}$ \\
\hline LAFAYETTE STATION & 165.5 & $\overline{\mathbb{N}}$ & $\overline{1}$ & $\overline{1}$ & 10 & ++4 \\
\hline LAFAYETTE YARD & 167.5 & $\mathbb{I N}$ & 1 & 1 & 10 & $\mathbf{Y}$ \\
\hline BROOKSTON & 180.0 & $\mathbb{I N}$ & 1 & 1 & 60 & $\mathbf{P}$ \\
\hline CHALMERS & 184.0 & $\overline{I N}$ & $T$ & $\overline{1}$ & 60 & $\bar{L}$ \\
\hline REYNOLDS & 790.75 & $\mathbb{T}$ & 7 & 1 & 60 & A \\
\hline MONON & 197.75 & IN & 1 & 1 & 60 & LYY \\
\hline RENSSELAER & 212.75 & $\mathbb{I N}$ & 1 & 1 & 60 & P,t,t+ \\
\hline SURREY & 218.5 & $\mathbb{I N}$ & $\overline{1}$ & $\overline{1}$ & 60 & LP \\
\hline ROSE LAWN & 230.5 & $\mathbf{I N}$ & 1 & 1 & 60 & L.P \\
\hline SHELBY & 234.5 & IN. NS & 1 & 1 & 60 & A \\
\hline $\begin{array}{l}\text { RM SCHAHFER POWER } \\
\text { STATION }\end{array}$ & 252.5 & NS & $\overline{1}$ & $\overline{5}$ & 40 & $T$ \\
\hline
\end{tabular}

Figure 13

Scenario 3 Route Timetable

To begin the analysis, consider the use of a single unit train dedicated from Farmersburg to Schahfer. This unit train consists of one hundred ten cars with a capacity of two hundred eighty six thousand pounds each. The target days-of-supply coal inventory is set at forty. Figure 15 displays the coal inventory at Schahfer with one unit train supplying its coal need. Clearly, the target coal inventory cannot be met with one unit train. According to the graph, one unit train can sustain a coal inventory between ten and fifteen days. 


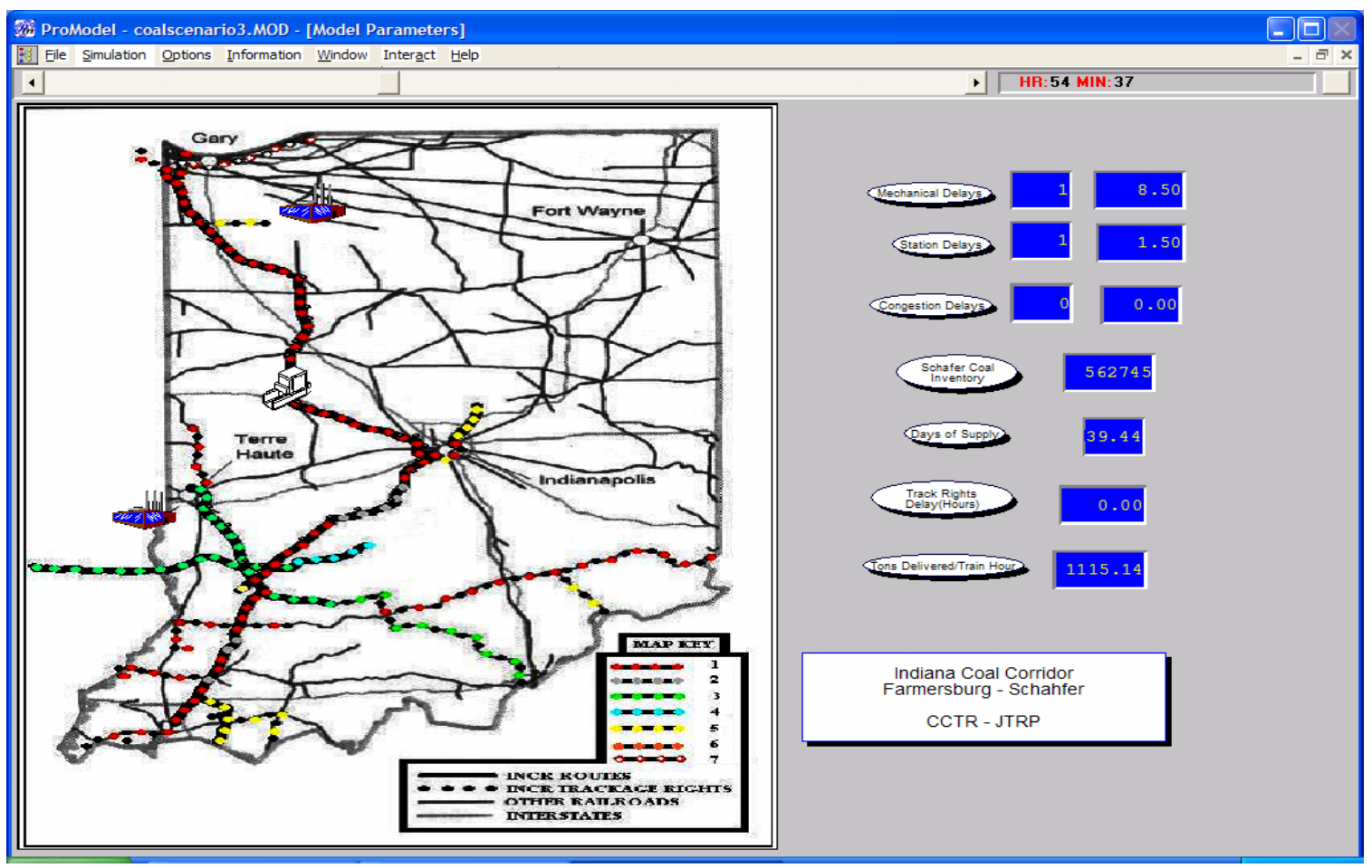

Figure 14

Scenario 3 Animation Screen

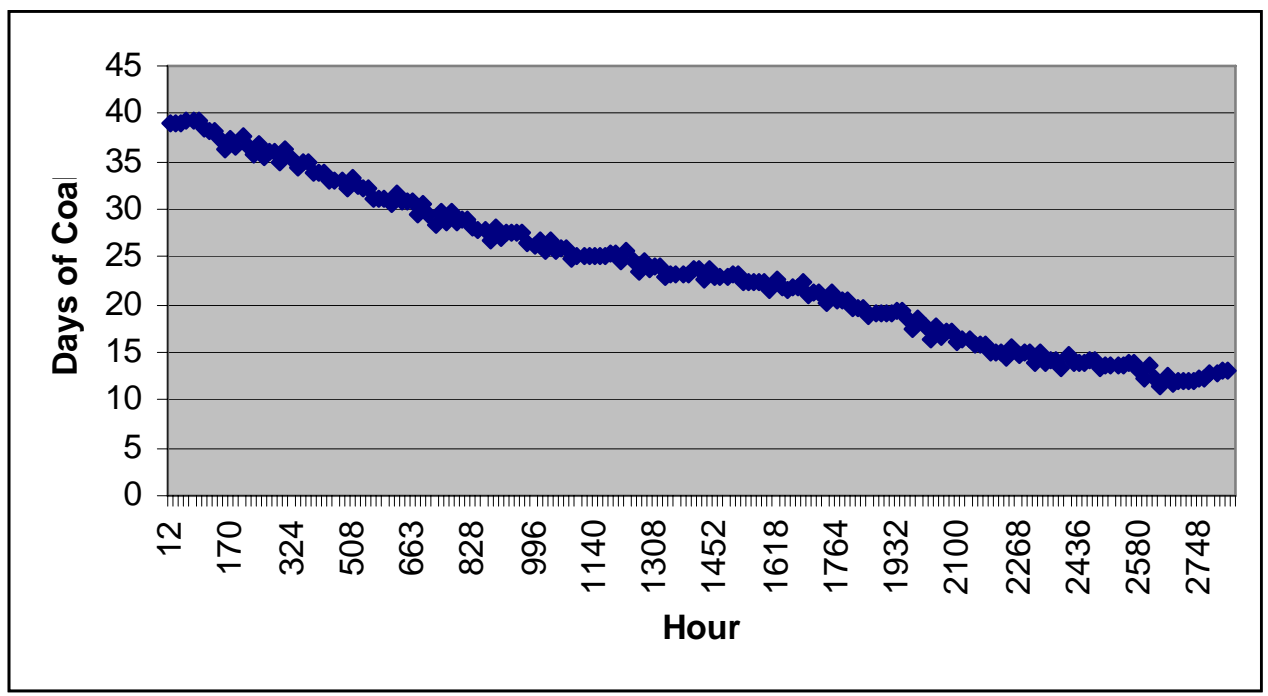

Figure 15

Coal Inventory Level Based On One Unit Train

Figure 16 depicts the days-of-supply in the Schahfer coal inventory if two unit trains are dedicated from Farmersburg. Two unit trains keep the inventory at a consistent level just below forty days. While running two unit trains provide the necessary coal, they represent nearly twelve percent of the NiSource fleet of coal hoppers [23]. 


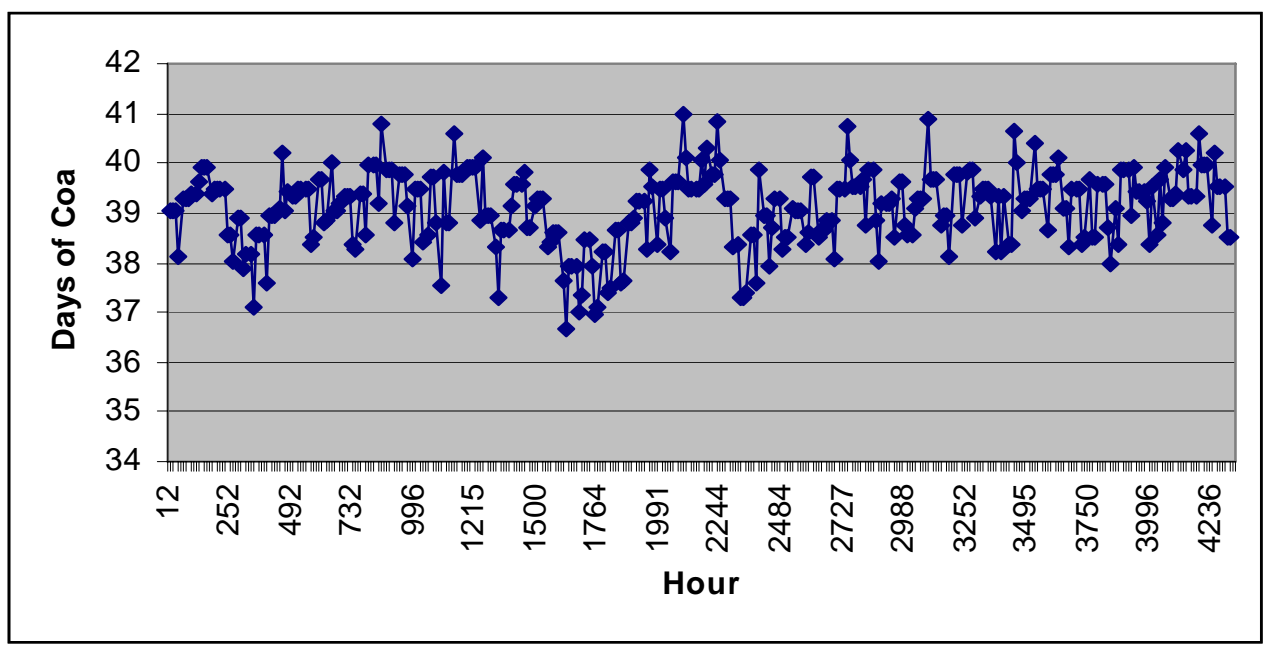

Figure 16

Coal Inventory Level Based On Two Unit Trains

Continuing with the analysis, assume that the rail connection between Farmersburg and Schahfer was all Class 1 . As part of this assumption, maximum train speed is set at sixty miles per hour, train length is set at one hundred twenty five hoppers, and the car capacity is set at three hundred fifteen thousand pounds [11]. Under this scenario, Figure 17 depicts the expected days-of-supply at Schahfer. The graph clearly shows that given a Class 1 rail infrastructure, one unit train would be sufficient to supply Schahfer's coal needs from the Farmersburg mine. This scenario clearly demonstrates the effect that rail infrastructure has on coal delivery.

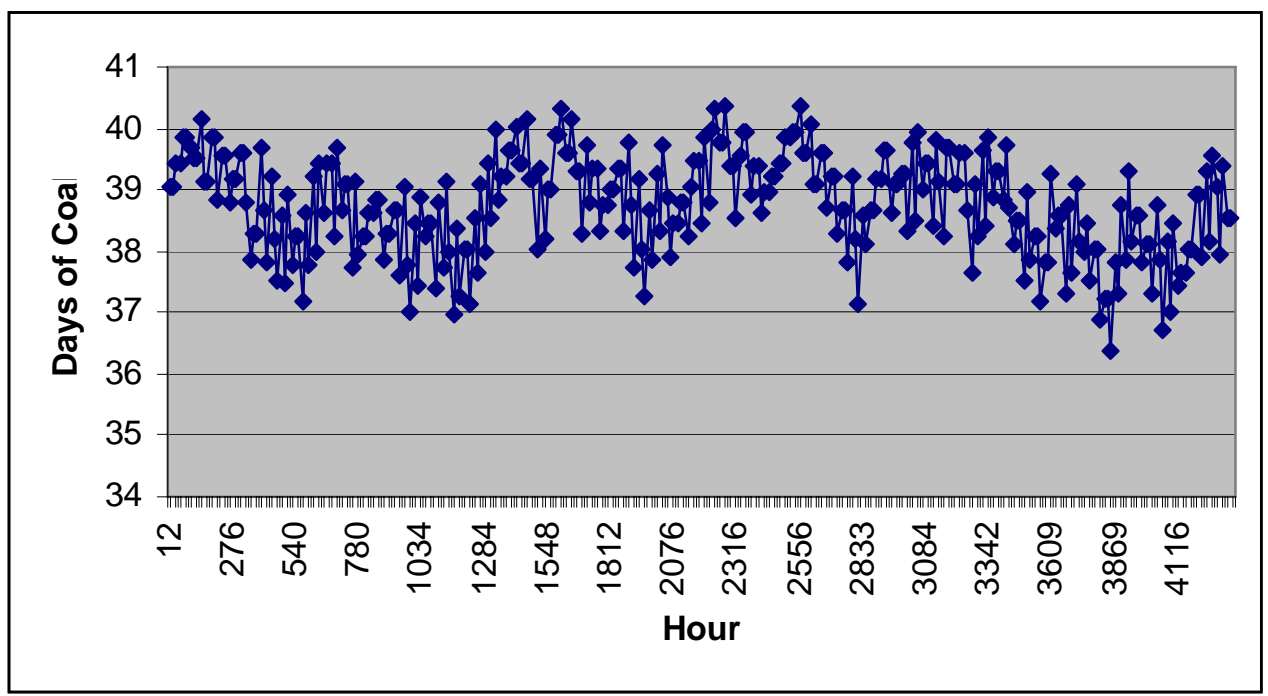

Figure 17

Coal Inventory Level Based On Class 1 Rail Infrastructure 


\section{Chapter 11}

\section{The INDIANA COAL CORRIDOR}

This chapter presents a preliminary concept dubbed the Indiana Coal Corridor. This concept addresses the movement of large quantities of coal and other commodities from southern Indiana mines and operations into northerly and southerly directions by suggesting a series of routes that could be assembled and operated by one entity. Movement of southern Indiana coal to the northern portion of the state can facilitate potential use in northern power plants or steel mills, barge shipment from the Port of Indiana to upper Great Lakes areas, or access to trans-continental BNSF, NS, or CSX markets through mainline connections in the Chicago area. Movement of coal to the southern portion of the state can facilitate potential use through shipment on barges on the Ohio to rail access points in the CSX network to the southeastern United States.

An attractive feature of this proposed concept is that it involves no capital investment in rail infrastructure. The requirement to make this proposal work would be the creation of a quasi-governmental private industry partnership that would essentially negotiate track rights from a number of large and small railroads. This entity would then assume marketing and operational details for the route. Through the use of the simulation model, various economic scenarios can be used to demonstrate proof of concept and economic feasibility and potential. The map of this concept is presented in Figure 8. Detailed timetables for the routes highlighted can be found in Appendix 2. These timetables can be used to create scenarios for unit coal trains traveling from southern Indiana mines to Chicago rail interchange points and northern Indiana power plants.

A scenario using the Indiana Coal Corridor concept to move coal from the Farmersburg mine in southern Indiana to the Schahfer power plant in northern Indiana is described in Chapter 10. This scenario is further embellished with the addition of passenger rail between Chicago and Indianapolis. Details of this scenario can be found in Chapter 12 . 


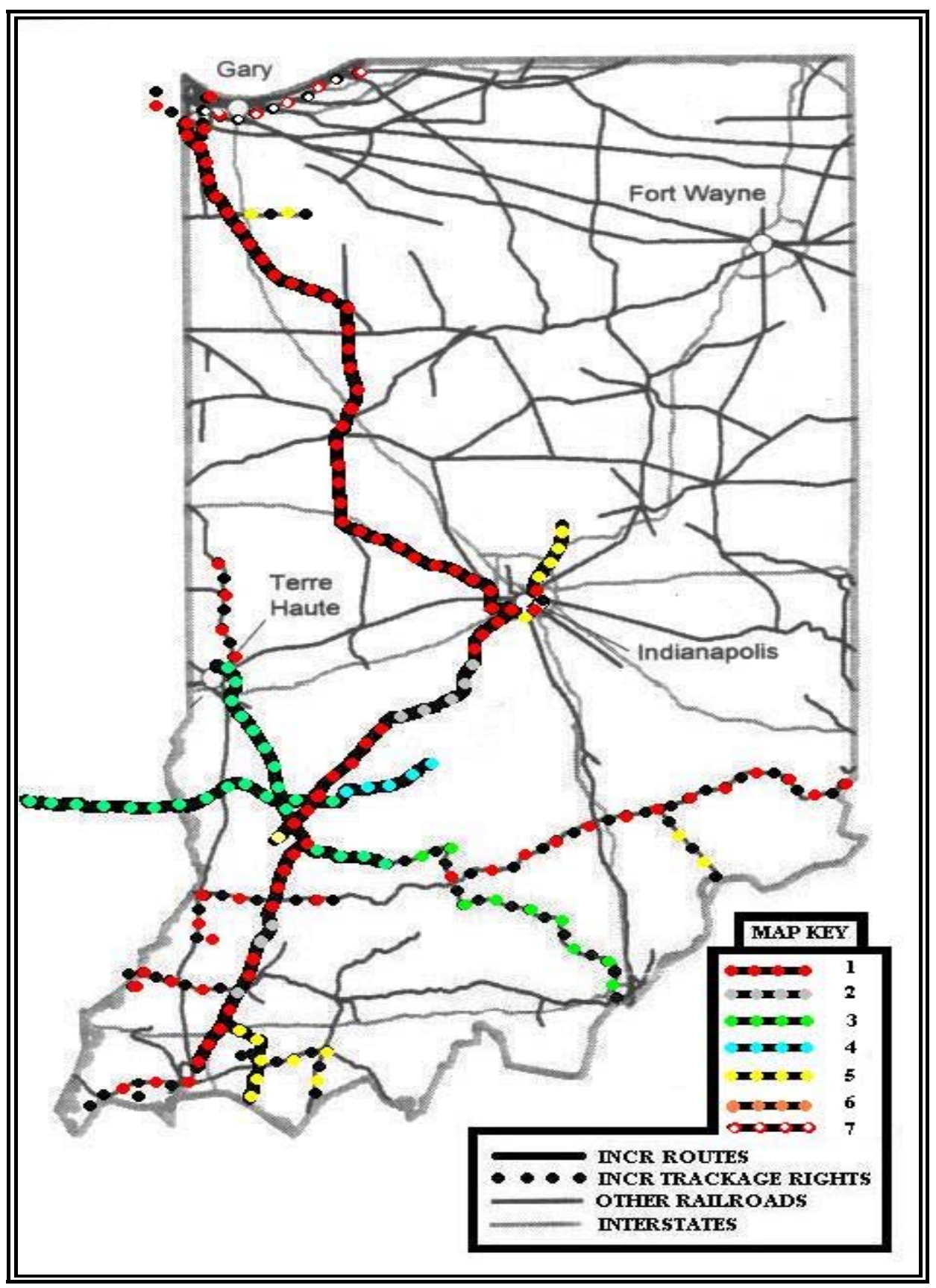

Figure 18

Proposed Indiana Coal Corridor 


\section{Chapter 12}

\section{SCENARIO 4: The INDIANA COAL CORRIDOR WITH LIGHT PASSENGER RAIL}

Chapter eleven discussed the conceptual development of an entity that would assemble a set of track right-of-ways that would form a south-north corridor in the state of Indiana. This corridor could be used to move any type of commodity from north to south or vice versa. This corridor opens up access to the Ports of Indiana international port in Burns Harbor, which opens up international opportunities for grain, coal, and container/intermodal shipments.

In this chapter, we extend the corridor concept to include high-speed passenger rail service from the Chicago/Northwest Indiana region to Indianapolis. This scenario was built upon the scenario discussed in Chapter 10 whereby the Schahfer power plant was supplied with coal from southern Indiana mines. The simulation model was used to examine the number of rail sidings that would be required to support travel time expectations between the light rail destination points. The computer simulation animation screen for this scenario is shown in Figure 19.

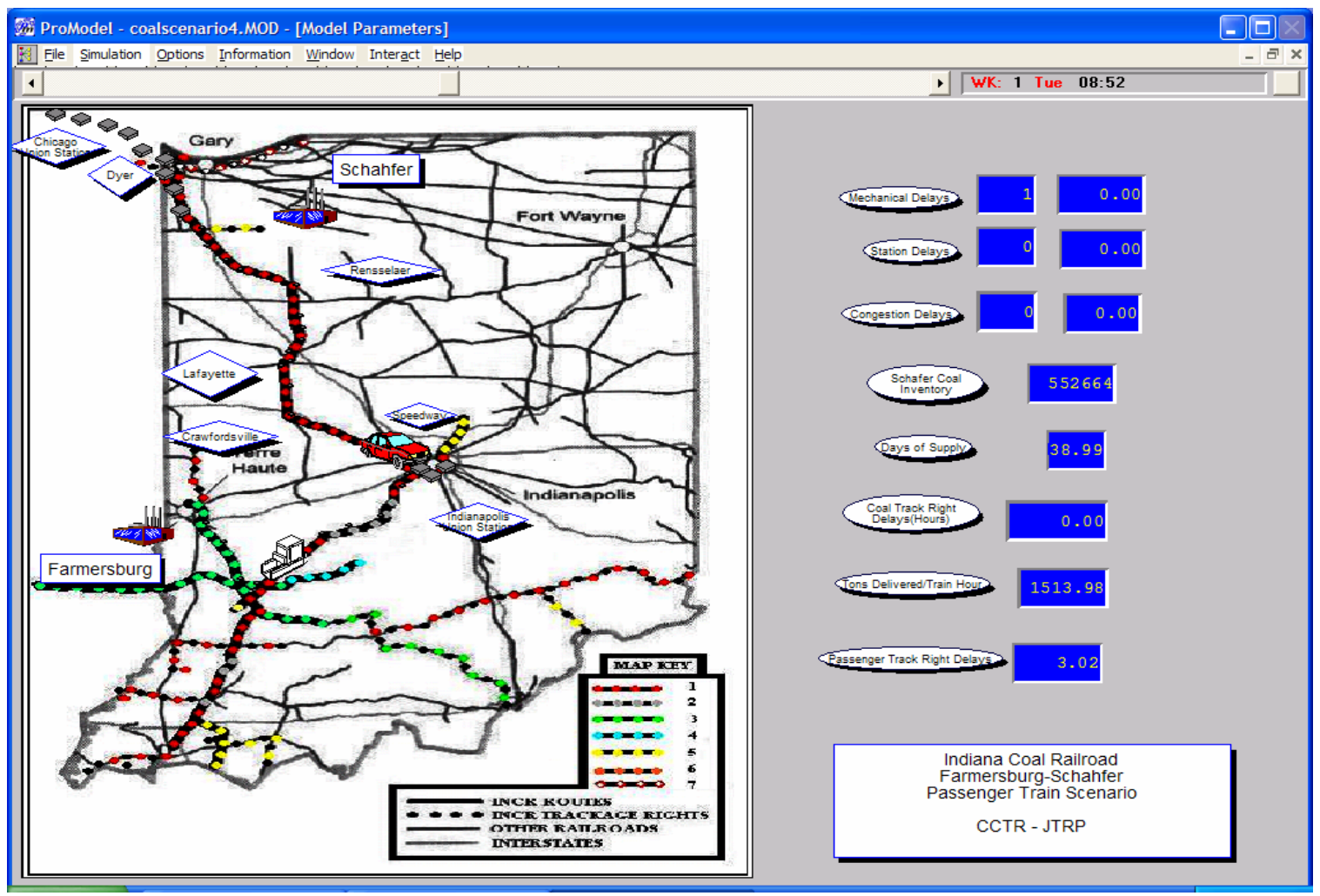

Figure 19

Scenario 4 Animation Screen 
The timetable used for the route between Chicago and Indianapolis is shown in Figure 20. Passenger stations are placed in Chicago, Dyer, Rensselaer, Lafayette, Crawfordsville, Speedway, and Indianapolis. The rail map is shown in Figure 21. One train per day is scheduled, leaving Chicago at six in the morning and departing Indianapolis at five in the afternoon.

INDIANA COAL RAILROAD TIMETABLE: SPEEDWAY CORRIDOR

\begin{tabular}{|c|c|c|c|c|c|c|c|}
\hline \multirow[t]{2}{*}{ STATION NAME } & \multirow{2}{*}{$\begin{array}{l}\text { MILE } \\
\text { POST }\end{array}$} & \multicolumn{4}{|c|}{ TRACK } & \multirow[t]{2}{*}{ NOTATION } & \multirow{2}{*}{$\begin{array}{l}\text { SCHEDULED } \\
\text { STOPS }\end{array}$} \\
\hline & & OWNER & MUMBER & CLASS & SPEED & & \\
\hline \multicolumn{8}{|c|}{ READ DOWWWARD FOR SOUTHBOUND } \\
\hline $\begin{array}{l}\text { CHICAGO UWION } \\
\text { STATION }\end{array}$ & 0.0 & AMTK & 2 & 1 & 10 &,+++ & 0:D0:D0 \\
\hline \multicolumn{8}{|c|}{ BETWEEN CHICAGO UNION STATION AND CANAL STREET YARD AMTK TIVETABLE GOVERNS. } \\
\hline $\begin{array}{l}\text { CAWAL STREET } \\
\text { YARD }\end{array}$ & 2.25 & $\begin{array}{c}\text { AMIK, } \\
\text { UP }\end{array}$ & 2 & 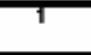 & 10 & $\mathrm{Y}$ & \\
\hline \multicolumn{8}{|c|}{ BETWEEN CANAL STREET YARD AND THOFNTON JCT UP TIMETABLE GONERNS. } \\
\hline THOFNTONJCT & 2225 & CN & 2 & 1 & 10 & $\mathrm{M}, \mathrm{X}$ & \\
\hline \multicolumn{8}{|c|}{ BETWEEN THORWTON JCT AND OAK GLENCN TIMETABLE GOVERNS. } \\
\hline OAK GLEN & 27.75 & $\mathrm{CN}$ & 2 & 1 & 600 & - & \\
\hline MAYNARD & 30.75 & CN, IN & 1 & 1 & 75 & - & \\
\hline DYER & 34.75 & $\mathbb{I N}$ & $\overline{1}$ & $\overline{1}$ & 75 & $M+, H$ & $0: 30: 45$ \\
\hline DYER SIDING & 36.75 & $\mathbf{I N}$ & 1 & 1 & 75 & L,P & \\
\hline ST. JOHN & 38.75 & IN & 1 & 1 & 75 & $\mathbf{A}$ & \\
\hline LOWEL & 49.75 & $\mathbb{I N}$ & $T$ & 1 & 75 & L, P & \\
\hline SHELBY & 57.75 & $\mathbf{I N}$ & 1 & 1 & 75 & A & \\
\hline ROSE LAWN & 61.75 & $\mathbb{I N}$ & 1 & 1 & 75 & L,P & \\
\hline SURREY & 73.75 & $\mathbb{I N}$ & 1 & 1 & 75 & L,P & \\
\hline RENSSELAER & 795 & $\mathbb{T N}$ & 7 & $T$ & 70 & $P,+,++$ & $0: 59: 30$ \\
\hline MONON & 94.5 & $\mathbb{I N}$ & 1 & 1 & 75 & $L, Y$ & \\
\hline REYNOLDS & 101.5 & $\mathbf{I N}$ & 1 & 1 & 75 & $\mathbf{A}$ & \\
\hline CHALMERS & 108.25 & $\overline{\mathbb{I N}}$ & $\overline{1}$ & $\overline{1}$ & 75 & $\mathbf{L}$ & \\
\hline BROOKSTON & 112.25 & IN & 1 & 1 & 75 & $\mathbf{P}$ & \\
\hline LAFAYETIE YARD & 124.75 & IN & 1 & 1 & 10 & $\bar{Y}$ & \\
\hline LAFAYEITE STATIOW & 126.75 & $\mathbb{I N}$ & 1 & 1 & 10 & $t+t+$ & $1: 30: 15$ \\
\hline LAFAYETTE JCT & 727.75 & $\mathbb{T I N}^{\mathbb{N}}$ & 7 & $T$ & 70 & $M$ & \\
\hline LINDEN & 142.75 & $\mathbb{I N}$ & 1 & 1 & 75 & L,P & \\
\hline CRAWFORSVILLE & 152.75 & IN & 1 & 1 & 75 & + & 1:41:15 \\
\hline BROWNSBURG & 182.75 & $\mathbb{I N}$ & 1 & 1 & 75 & - & \\
\hline $\begin{array}{l}\text { SPEEDWAY (CP } \\
\text { CLERMONT) } \\
\end{array}$ & 186.5 & IN & 1 & 2 & 40 & $+H$ & $1: 58: 30$ \\
\hline CPHUNT & 189.5 & $\mathbb{I N}$ & 1 & 2 & 10 & - & \\
\hline CPHOLT & 198.25 & IN, INCR & 1 & $\overline{2}$ & 20 & $\bar{T}$ & \\
\hline TRANSFER YARD & 19925 & IN, INCR & 1 & 2 & 10 & $\mathbf{Y}$ & \\
\hline CP WOOD & 199.75 & CSXT, IN & 2 & 1 & 10 & - & \\
\hline \multicolumn{8}{|c|}{ BETWEEN CP WOOD AND INDIANAPOLIS UNION STATION CSXT TIVETABLE GOVERTS. } \\
\hline $\begin{array}{l}\text { INDLANAPOLIS } \\
\text { UNMON STATION }\end{array}$ & 200.5 & CSXT & 2 & 1 & 10 &,+++ & 2:12:30 \\
\hline
\end{tabular}

Figure 20

Scenario 4 Route Timetable

Model results indicate that the travel time between the regions, assuming class 1 rail and ideal operating conditions concerning congestion, delay, and mechanical breakdown for the entire route could be in the range of 110 minutes.

However, when unit coal trains serving Schahfer from southern Indiana coalmines were added to the route, the passenger train was made subject to the operational conditions defined in Chapter 7, and four right-of-way zones were created with FIFO controls, the one way travel time reached nearly five hours. This is clearly not an acceptable, since passenger rail success depends on quick, reliable service. Further analysis of this scenario, with emphasis on adding additional track sidings at optimal locations, and determination of optimal right-of-way policy can facilitate the development of a high 
speed passenger rail system that will serve the state of Indiana and become a catalyst for high speed rail within the Midwest. A successful high speed rail system as proposed on the Indiana Coal Corridor would open up growth and economic opportunities for communities located on the route such as Crawfordsville, Renssalaer, and Lafayette by connecting them to major economic hubs. 


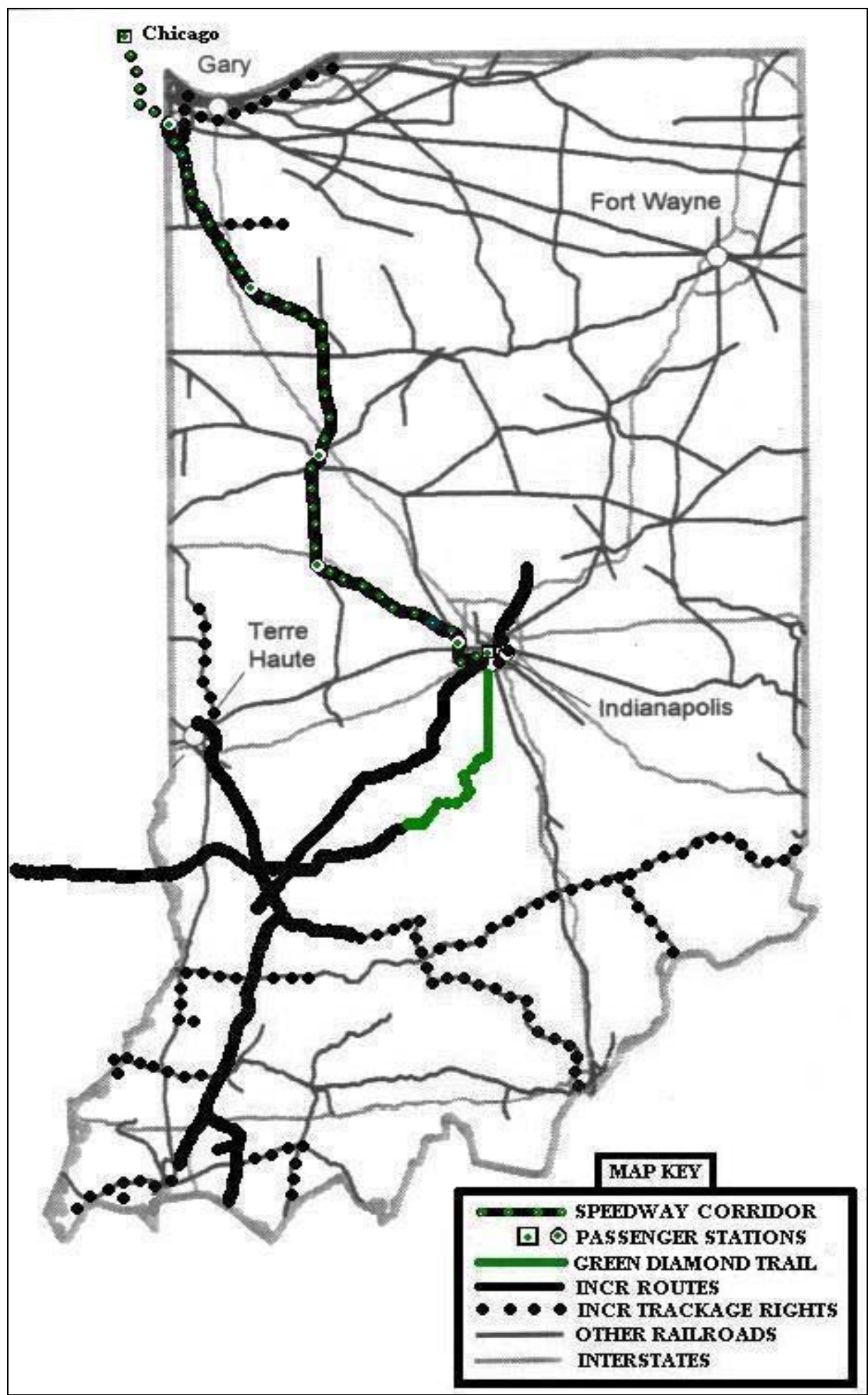

Figure 21

Passenger Rail Routes 


\section{Chapter 13}

\section{OPTIMAL ALLOCATION OF INFRASTRUCTURE INVESTMENT}

Throughout this project, the assumption was made that the rail infrastructure in the state of Indiana was fixed. This chapter explores the concept of intelligent investment in the rail infrastructure. As described in Chapter 5, Indiana possesses over four thousand miles of rail that exists in all class definitions. This chapter describes the development of an optimization model that allocates investment dollars to individual links in the state of Indiana rail infrastructure in a manner that maximizes the overall average class value of the infrastructure.

As described in Chapter 5, Class 1 rail infrastructure permits maximum throughput. The objectives of optimization model described below is to examine each link in the rail infrastructure not currently rated Class 1 and select the best set of links for upgrade that satisfy constraints of total investment dollars and upgrade policy.

Table 10 presents hypothetical upgrade cost per mile based upon standard rail class definitions. These upgrade costs represent the cost per mile to upgrade from the given class to class 1 . For example, the cost per mile to upgrade from class 4 to class 1 is $\$ 800,000$. The ability to upgrade to conditions other than class 1 , for example from class 4 to class 2, is not considered due to scope limitations for this project. The ability to consider this type of upgrade investment is a straightforward extension to the model and could be added at a later time.

\begin{tabular}{|c|c|}
\hline Class & Upgrade Cost/Mile \\
\hline 5 & $\$ 1,000,000$ \\
\hline 4 & $\$ 800,000$ \\
\hline 3 & $\$ 600,000$ \\
\hline 2 & $\$ 200,000$ \\
\hline
\end{tabular}

Table 10

Hypothetical Rail Upgrade Costs

The formulation for the optimization model is as follows:

$\operatorname{Min} C_{5} \sum_{i}^{n} l_{i} x 5_{i}+C_{4} \sum_{i}^{n} l_{i} x 4_{i}+C_{3} \sum_{i}^{n} l_{i} x 3_{i}+C_{2} \sum_{i}^{n} l_{i} x 2_{i}$

Subject to:

$\sum_{i}^{n} l_{i} x 5_{i} \geq m_{5}$ 
$\sum_{i}^{n} l_{i} x 4_{i} \geq m_{4}$

$\sum_{i}^{n} l_{i} \times 3_{i} \geq m 3$

$\sum_{i}^{n} l_{i} x 2_{i} \geq m_{2}$

Where

$\mathrm{n}$ is defined as the number of links

$\mathrm{l}$ is defined as the length of an individual link

$\mathrm{C}_{5}$ is defined as the cost per mile to upgrade Class 5 to Class 1

$\mathrm{C}_{4}$ is defined as the cost per mile to upgrade Class 4 to Class 1

$\mathrm{C}_{3}$ is defined as the cost per mile to upgrade Class 3 to Class 1

$\mathrm{C}_{2}$ is defined as the cost per mile to upgrade Class 2 to Class 1

m5 is defined as the minimum number of Class 5 miles to upgrade $\mathrm{m} 4$ is defined as the minimum number of Class 4 miles to upgrade $\mathrm{m} 3$ is defined as the minimum number of Class 3 miles to upgrade $\mathrm{m} 2$ is defined as the minimum number of Class 2 miles to upgrade

To demonstrate the usefulness of the optimization model, consider the rail infrastructure that exists between the Cypress Creek Mine and the Tanners Creek Power Plant and the Farmersburg Mine and the Clifty Creek Power Plant. The timetables for these connections and the associated optimization structure are shown in Table 11 (on page 46 of this report). There are a total of forty links in these routes, including eleven that are common to both routes. Table 12 shows the distribution of track miles by class. Approximately forty-eight percent of the rail mileage is not Class 1.

\begin{tabular}{|l|l|l|}
\hline Class & Links & Miles \\
\hline 1 & 21 & 190 \\
\hline 2 & 9 & 108 \\
\hline 3 & 7 & 37 \\
\hline 4 & 0 & 0 \\
\hline 5 & 3 & 3 \\
\hline 6 & 0 & 0 \\
\hline
\end{tabular}

Table 12

Distribution of Miles by Class

Assume that a rail investment plan policy was developed that wanted to upgrade at least 10 miles of Class 5 track, 0 miles of Class 4 track, 15 miles of Class 3 track, and 35 miles of Class 2 track within these two routes. The problem facing the policy makers is to 
select the set of links that meet these minimum upgrade values for each class of rail while minimizing total cost.

Using this example, the optimization formulation was coded using the Solver tool in Microsoft Excel. The column labeled DV in Table 11 represents the answer for the optimization model. Any link with a value of one in the DV column is to be upgraded to Class 1 . Table 13 presents a summary of the answer obtained for this problem.

\begin{tabular}{|c|c|c|c|c|}
\hline Class & Total Links & Links to Upgrade & Target Miles to Upgrade & Miles to Upgrade \\
\hline 1 & 21 & 0 & 0 & 0 \\
\hline 2 & 9 & 4 & 35 & 37 \\
\hline 3 & 7 & 3 & 15 & 15 \\
\hline 4 & 0 & 0 & 0 & 0 \\
\hline 5 & 3 & 1 & 10 & 24 \\
\hline 6 & 0 & 0 & 0 & 0 \\
\hline
\end{tabular}

Table 13

Optimization Summary

The model answer suggested an upgrade plan that involved eight links at a total cost of forty million dollars. These links are identified with a value of 1 in the DV column in Table 11. This cost is based on the hypothetical upgrade costs given in Table 10.

This type of optimization formulation belongs to the resource allocation class of problems. While these types of problems are easy to formulate, they become extremely difficult to solve as the number of variables increase. The set of timetables developed in this project contain nearly four hundred links. Given the cost of rail upgrade and the complexity of the infrastructure as a whole, optimization models such as the one developed in this chapter can be invaluable to policy makers attempting to maximize the effectiveness of a limited amount of investment dollars. 
A Prescriptive Analysis of the Indiana Coal Transportation Infrastructure Brady, Pfitzer

\begin{tabular}{|c|c|c|c|c|c|c|c|c|c|}
\hline \multicolumn{5}{|c|}{ SCHEDULE 9.8: CYPRESS CREEK MINE - TANNERS CREEK POWER } & DV & \multirow{2}{*}{$\begin{array}{c}5 \\
1\end{array}$} & \multirow[t]{2}{*}{4} & \multirow[t]{2}{*}{3} & \multirow[t]{2}{*}{2} \\
\hline CYPRESS CREEK MINE 0.0 INCR 1520 T & 0 & 5 & 20 & 0 & 0 & & & & \\
\hline BUCKSKIN 6.0 INCR $1520 \mathrm{~T}$ & 6 & 5 & 20 & 6 & 0 & 1 & & & \\
\hline SOMERVILLE 9.0 INCR $1140 \mathrm{~T}$ & 9 & 1 & 40 & 3 & 0 & & & & \\
\hline GRAY JCT 13.0 INCR 1140 - & 13 & 1 & 40 & 4 & 0 & & & & \\
\hline OAKLAND CITY 14.0 INCR 1140 A & 14 & 1 & 40 & 1 & 0 & & & & \\
\hline ASHBY YARD 24.5 INCR 1140 B,E,Y & 24.5 & 1 & 40 & 10.5 & 0 & & & & \\
\hline PETERSBURG 26.0 INCR 1140 - & 26 & 1 & 40 & 1.5 & 0 & & & & \\
\hline CHAPPEL 43.0 INCR 1225 M & 43 & 2 & 25 & 17 & 1 & & & & 1 \\
\hline ELNORA 62.0 INCR $1140 \mathrm{~A}$ & 62 & 1 & 40 & 19 & 0 & & & & \\
\hline ODON 68.0 INCR 1340 - & 68 & 3 & 40 & 6 & 1 & & & 1 & \\
\hline CRANE 76.0 CSXT, & 76 & 3 & 40 & 8 & 0 & & & 1 & \\
\hline BEDFORD 100.0 CSXT 1225 - & 100 & 2 & 25 & 24 & 0 & & & & 1 \\
\hline MITCHELL 110.0 CSXT 1225 L, M, P, T & 110 & 2 & 25 & 10 & 0 & & & & 1 \\
\hline SPARKSVILLE 125.75 CSXT $1140 \mathrm{~L}$ & 125.75 & 1 & 40 & 15.75 & 0 & & & & \\
\hline MEDORA 130.0 CSXT 1140 L, P & 130 & 1 & 40 & 4.25 & 0 & & & & \\
\hline BROWNSTOWN 140.0 CSXT 1140 L, P & 140 & 1 & 40 & 10 & 0 & & & & \\
\hline SEYMOUR 150.0 CSXT $1140 \mathrm{~L}, \mathrm{P}$ & 150 & 1 & 40 & 10 & 0 & & & & \\
\hline NORTH VERNON 156.0 CSXT $1140 \mathrm{~L}$ & 156 & 1 & 40 & 6 & 0 & & & & \\
\hline BUTLERVILLE 165.0 CSXT $1140 \mathrm{~L}, \mathrm{P}$ & 165 & 1 & 40 & 9 & 0 & & & & \\
\hline OSGOOD 186.0 CSXT $1140 \mathrm{~L}, \mathrm{P}$ & 186 & 1 & 40 & 21 & 0 & & & & \\
\hline MILAN 194.5 CSXT 1140 L, P, T & 194.5 & 1 & 40 & 8.5 & 0 & & & & \\
\hline COCHRAN JCT 208.25 CSXT 1225 L & 208.25 & 2 & 25 & 13.75 & 1 & & & & 1 \\
\hline AURORA 212.0 CSXT 1225 & 212 & 2 & 25 & 3.75 & 1 & & & & 1 \\
\hline LAWRENCEBURG 216.0 CSXT 1225 & 216 & 2 & 25 & 4 & 0 & & & & 1 \\
\hline TANNERS CREEK & 218 & 2 & 25 & 2 & 1 & & & & 1 \\
\hline SCHEDULE 2.5: FARMERSBURG MINE - C & TY CRE & JEF & $\mathrm{ION}$ & & 0 & & & & \\
\hline KELLER 0.0 INCR $1340 \mathrm{P}, \mathrm{T}$ & 0 & 3 & 40 & 0 & 0 & & & 1 & \\
\hline LATTA 5.0 INCR 1320 B,E,T,Y & 5 & 3 & 20 & 5 & 1 & & & 1 & \\
\hline LINTON 9.0 INCR 1320 A & 9 & 3 & 20 & 4 & 1 & & & 1 & \\
\hline BEEHUNTER 14.0 INCR $1140 \mathrm{~A}$ & 14 & 1 & 40 & 5 & 0 & & & & \\
\hline ELNORA 20.0 INCR $1140 \mathrm{~A}$ & 20 & 1 & 40 & 6 & 0 & & & & \\
\hline ODON 26.0 INCR 1340 - & 26 & 3 & 40 & 6 & 0 & & & 1 & \\
\hline CRANE 34.0 CSXT, & 34 & 3 & 40 & 8 & 0 & & & 1 & \\
\hline BEDFORD 58.0 CSXT 1225 - & 58 & 2 & 25 & 24[ & 0 & & & & 1 \\
\hline MITCHELL 68.0 CSXT 1225 L, M, P, T & 68 & 2 & 25 & 10 & 0 & & & & 1 \\
\hline SPARKSVILLE 183.75 CSXT $1140 \mathrm{~L}$ & 83.75 & 1 & 40 & 15.75 & $\overline{0}$ & & & & \\
\hline MEDORA 88.0 CSXT $1140 \mathrm{~L}, \mathrm{P}$ & 88 & 1 & 40 & 4.25 & 0 & & & & \\
\hline BROWNSTOWN 97.0 CSXT 1140 L, P & 97 & 1 & 40 & 9 & 0 & & & & \\
\hline SEYMOUR 108.0 CSXT 1140 L, P & 108 & 1 & 40 & 11 & 0 & & & & \\
\hline NORTH VERNON 123.0 CMPA, & 123 & 1 & 40 & 15 & 0 & & & & \\
\hline MADISON 147.0 CMPA $1525 \mathrm{~T}$ & 147 & 5 & 25 & 24 & 1 & 1 & & & \\
\hline
\end{tabular}

Table 11

Optimization Formulation Data 


\section{Chapter 14}

\section{CONCLUSIONS and SUGGESTIONS for FURTHER RESEARCH}

Throughout the duration of this project, we have been encouraged by the significant amount of interest in the methodology and results. We are also encouraged by the increasing number of suggested scenarios to analyze.

The major contributions of this project include the development of railroad timetables between coal producers and coal consumers in the state of Indiana and a simulation framework that can provide insight into current and proposed rail-based scenarios. These timetables can be used as the basis for an unlimited amount of further analysis. This project has demonstrated that the methodology works and can provide useful insight into rail operations.

The results and methodology of this project can be extended in two directions:

\section{Extension 1: Analyze More Scenarios}

Many scenarios have been suggested for analysis, but could not be accommodated due to the scoping nature of this project. In its present form, the timetables and simulation model can be used to analyze issues including but not limited to:

1. The shipment of Southern Indiana coal to Crane.

2. Vectren transportation issues in southern Indiana and the potential supply to northern Indiana.

3. The integration of water as a means of coal shipment, including the Great Lakes and the Ohio River.

4. Movement of southern Indiana coal into the national coal transportation rail networks in the Chicago area.

\section{Extension 2: Extend the methodology}

Expand the scope of the analysis to include the following items:

1. All users of coal in the state, with emphasis on the Northwest Indiana steel industry and their coking needs.

2. All coal-fired power plants in Indiana. 
3. All coal mines in Indiana.

4. All rail commodities, including intermodal and grain. This would allow analysis concerning the substitution effects of grain for coal, etc., in anticipation of ethanol and bio-diesel transportation needs.

The most significant extension of the project would be to include the possibility of adding new rail links to the present rail infrastructure. There are several links suggested that could be added in the north part of the state that would allow convenient rail traffic to avoid the congested south Chicago rail interchange.

We believe that extensions to this project can be leveraged into a significant full-scale study of the Indiana coal transportation infrastructure. This would allow policy makers to acquire detailed, accurate estimates of performance over the Indiana rail infrastructure. 


\section{REFERENCES}

1. “A Power Grid for the Hydrogen Economy.” Scientific American July 2006.

2. “A Texas Coal Rush.” Fortune February 19, 2007.

3. Alliance Resource Partners Annual Report 2005.

4. Black, William R., 2006, Freight Flows of Indiana, Joint Transportation Research Program, Indiana Department of Transportation, Purdue University.

5. City of Vincennes/CSX Transportation, 2002, Roadway/Railroad Crossing Conflict Mitigation Feasibility Study, HDR Engineering, Inc.

6. “Coal Traffic Spirals Higher.” Trains Magazine September 2006.

7. EnergyBiz Insider, 20 January 2006.

8. “Energy’s Future Beyond Carbon.” Scientific American September 2006.

9. "Freight boom benefits Chicago; tie-ups show infrastructure needs." Chicago Tribune 27 March 2006.

10. Goodell, Jeff. Big Coal: The Dirty Secret Behind America's Energy Future New York: Houghton Mifflin, 2006.

11. “How Heavy Can Freight Cars Get?” Trains Magazine March 2006.

12. Indiana Coal Report 2006, Center for Coal Technology Research, The Energy Center at Discovery Park, Purdue University.

13. “Indiana Digs in for new coal demand.” Indianapolis Star 13 April 2006.

14. Law, Averill M., Kelton, W. David. Simulation Modeling \& Analysis. New York: McGraw-Hill, 1991.

15. “Old King Coal Comes Back.” Fortune Feb 21, 2005.

16. Pitt, David. "Ethanol fueling expansion in transportation” The Indianapolis Star 10 November 2006.

17. “Pumping Coal.” Scientific American May 2006.

18. Quinn, Steve. “US has coal to burn.” Lafayette Journal \& Courier 16 Oct 2006. 
19. "Railroads struggle to meet demands for coal.” Post Tribune 11 June 2006.

20. Railroad Facts 2006 Edition. Association of American Railroads. Washington, DC.

21. "Snags in Wyoming Ripple Through Taxed network: Power Plants Run Short." Wall Street Journal 15 March 2006.

22. The Illinois Coal Industry, Report of the Office of Coal Development, December 2004.

23. The Official Railway Equipment Register. Volume 122, No. 2. October 2006. R.E.R. Publishing. East Windsor, NJ.

24. Vollmann, Berry, Whybark, \& Jacobs. Manufacturing Planning \& Control for Supply Chain Management. New York: McGraw-Hill, 2007.

25. Wald, Matthew L. "Power-grid report suggest dark days ahead.” The Indianapolis Star 10 Oct 2006.

26. "What it Takes to Build a 21 ${ }^{\text {st }}$ Century Railroad.” Fortune March 20, 2006.

27. "Wheatfield generating station hits new power use record.” Post Tribune 27 July 2006.

28. “Will Ethanol Help Fuel the Rail Traffic Boom?” Trains Magazine August 2006.

29. 2006 US Coal Industry Map; Global Energy Decisions, LLC. 
A Prescriptive Analysis of the Indiana Coal Transportation Infrastructure Brady, Pfitzer

APPENDICES 1 and 2 are available on the CCTR website:

http://discoverypark.purdue.edu/wps/portal/Energy/CCTR_Research 